

\section{The glass industry: Recent trends and changes in working conditions and employment relations}

Nora Wintour

International Labour Office

Geneva

Working papers are preliminary documents circulated to stimulate discussion and obtain comments 
Copyright ( ) International Labour Organization 2015

First published 2015

Publications of the International Labour Office enjoy copyright under Protocol 2 of the Universal Copyright Convention. Nevertheless, short excerpts from them may be reproduced without authorization, on condition that the source is indicated. For rights of reproduction or translation, application should be made to ILO Publications (Rights and Licensing), International Labour Office, CH-1211 Geneva 22, Switzerland, or by email: rights@ilo.org. The International Labour Office welcomes such applications.

Libraries, institutions and other users registered with a reproduction rights organization may make copies in accordance with the licences issued to them for this purpose. Visit www.ifrro.org to find the reproduction rights organization in your country.

\section{ILO Cataloguing in Publication Data}

Wintour, Nora

The glass industry : recent trends and changes in working conditions and employment relations / Nora Wintour ; International Labour Office, Sectoral Policies Department. - Geneva: ILO, 2015

(Working paper ; WP 310)

ISBN: $9789221301172 ; 9789221301189$ (web pdf)

International Labour Office Sectoral Policies Dept.

glass industry / manufacturing / employment / technological change / occupational safety / social dialogue / role of ILO

08.10 .4

ILO Cataloguing in Publication Data

The designations employed in ILO publications, which are in conformity with United Nations practice, and the presentation of material therein do not imply the expression of any opinion whatsoever on the part of the International Labour Office concerning the legal status of any country, area or territory or of its authorities, or concerning the delimitation of its frontiers.

The responsibility for opinions expressed in signed articles, studies and other contributions rests solely with their authors, and publication does not constitute an endorsement by the International Labour Office of the opinions expressed in them.

Reference to names of firms and commercial products and processes does not imply their endorsement by the International Labour Office, and any failure to mention a particular firm, commercial product or process is not a sign of disapproval.

ILO publications and digital products can be obtained through major booksellers and digital distribution platforms, or ordered directly from ilo@turpin-distribution.com. For more information, visit our website: www.ilo.org/publns or contact ilopubs@ilo.org. 


\section{Contents}

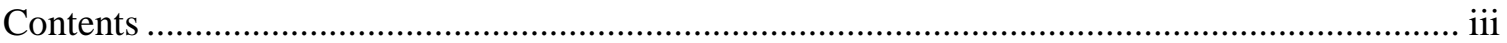

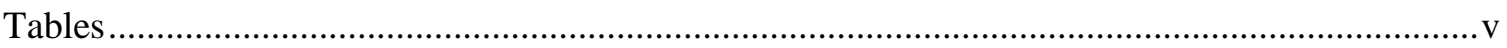

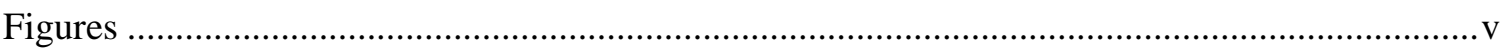

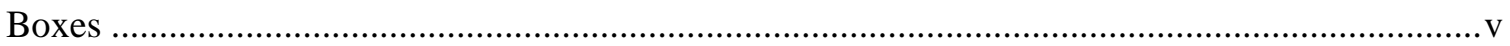

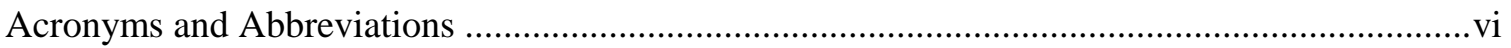

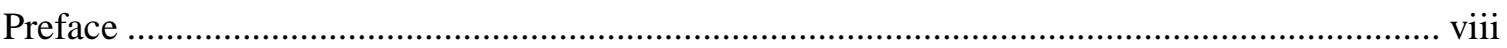

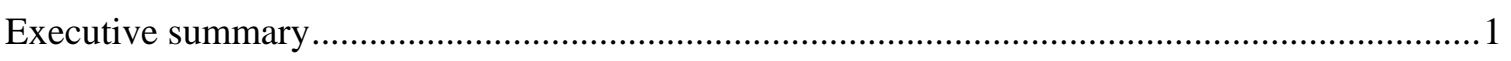

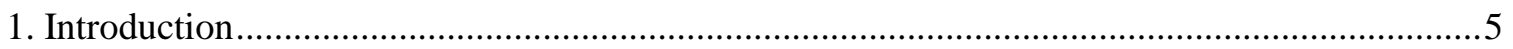

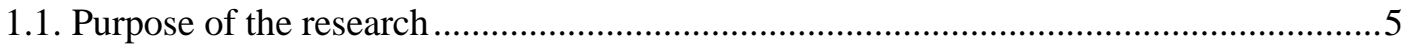

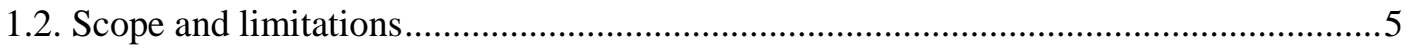

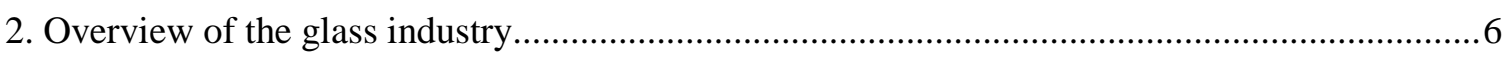

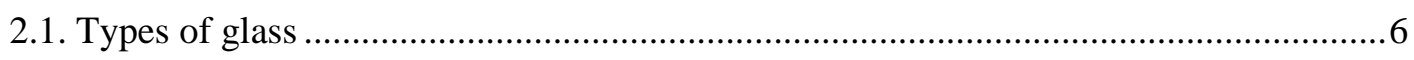

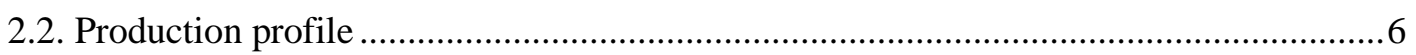

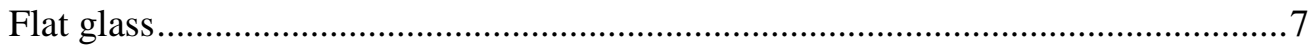

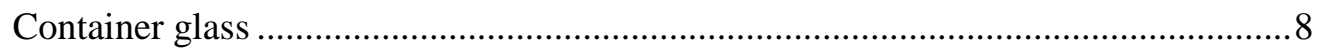

2.3. Selected country and regional profiles.....................................................................

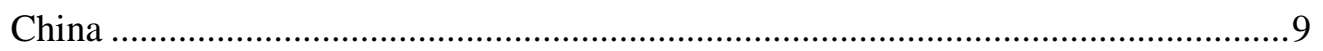

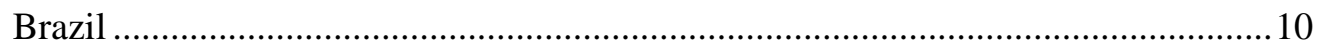

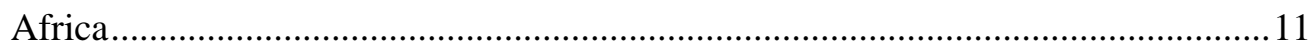

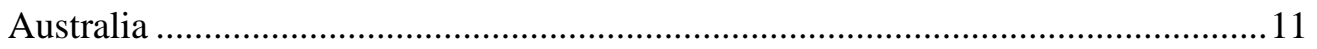

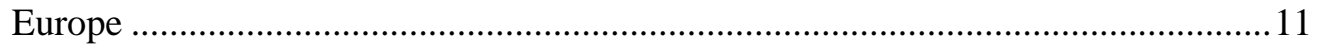

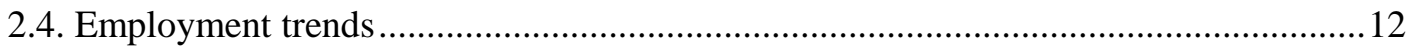

2.5. Increasing consolidation of production by large multinational enterprises ................... 12

Selected company profiles............................................................................ 13

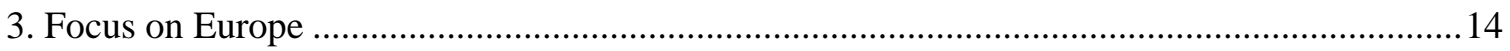

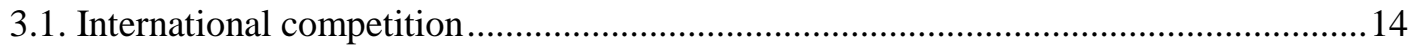

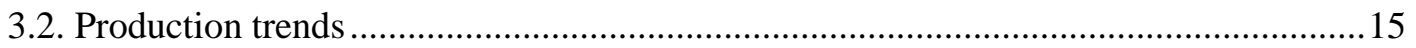

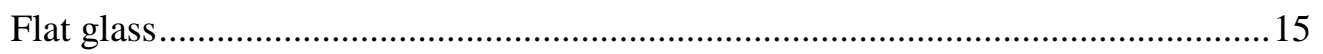

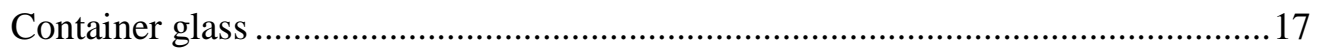

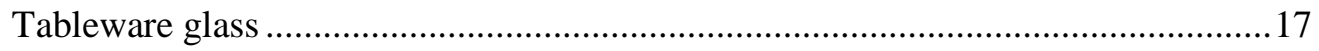

Glass fibre reinforced plastic (GRP) …......................................................... 18

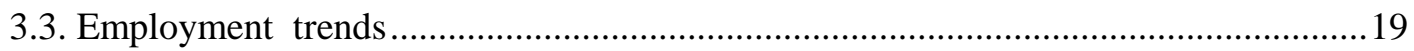

4. Occupational health and safety in the glass manufacturing industry .......................................22 


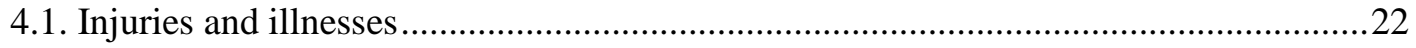

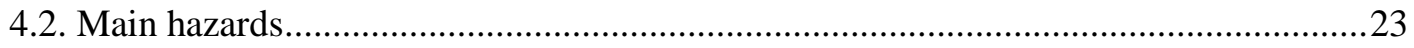

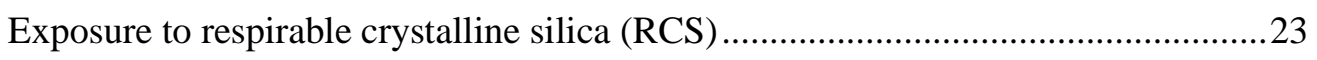

4.3. ILO Guidelines on occupational safety and health management systems (ILO-OSH 2001) .25

4.4. Workplace practices and OSH committees in the Asia and Americas regions ............26

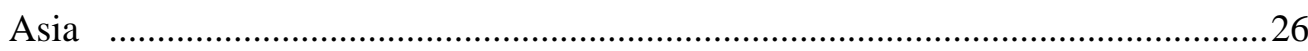

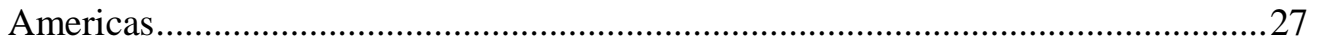

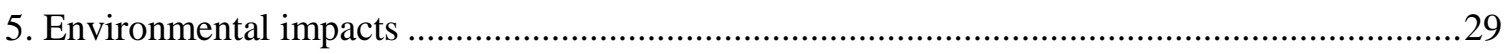

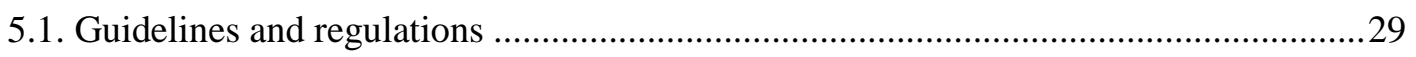

International Finance Corporation EHS Guidelines ................................................29

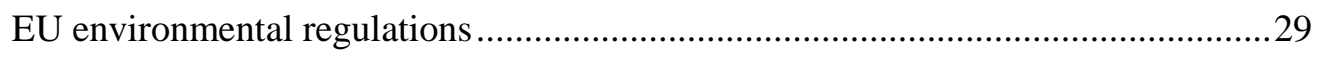

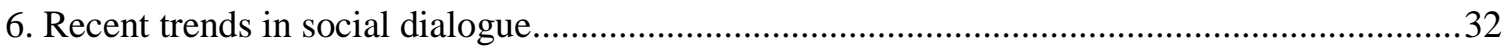

6.1. Social dialogue in the glass industry at global level .................................................... 32

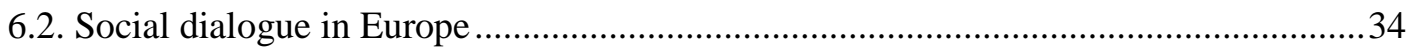

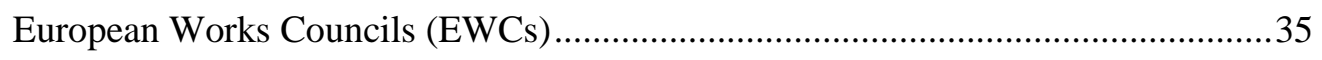

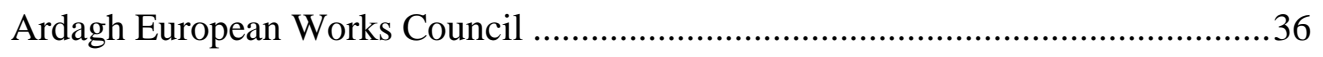

Saint-Gobain Convention for European Dialogue......................................................37

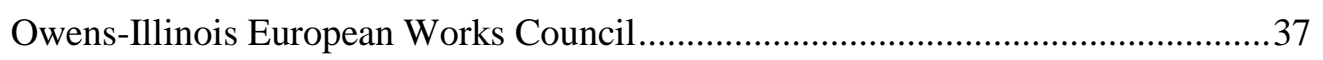

France: Social dialogue in the context of economic recession and job losses............37

United Kingdom: Promoting fair pay and limiting precarious work...........................38

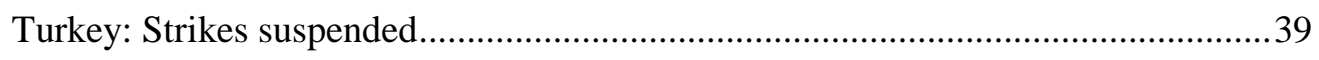

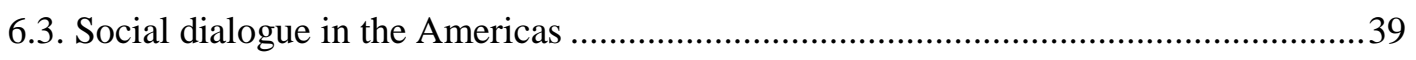

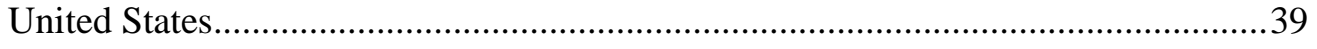

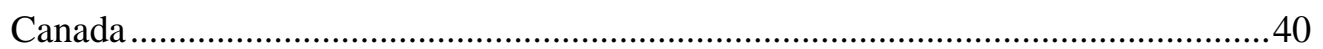

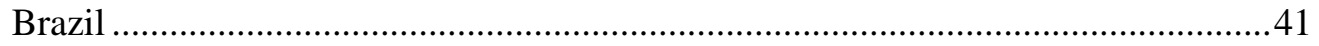

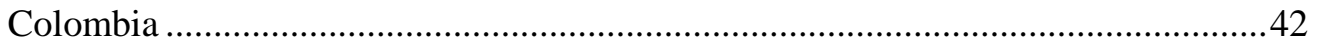

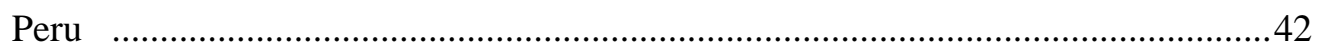

6.4. Social dialogue in Asia: Selected countries ................................................................43

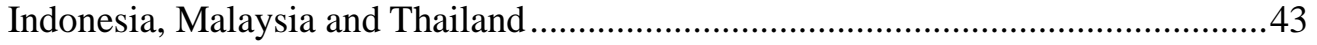

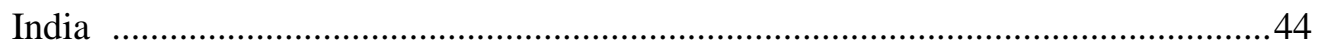

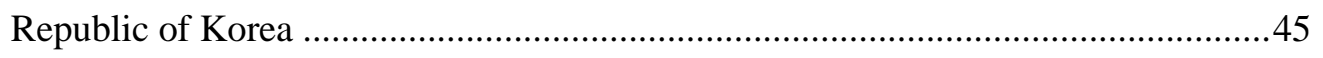

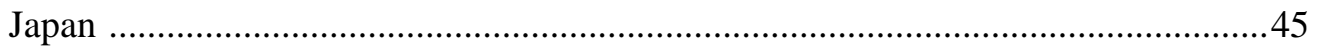

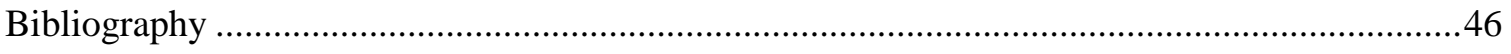

Annex. Employment in the glass and glass production sector, selected countries, 2000-2012 ....50 


\section{Tables}

Table 1. Brazil: Production and investment in the flat glass industry, 2007-11 ..........................10

Table 2. Brazil: Production and investment in the container glass industry, 2007-11 .................11

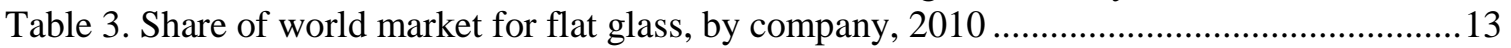

Table 4. Employment in the glass industry, selected European countries, 2007 and 2013 ...........20

Table 5. Incidence rates 1 of non-fatal occupational injuries in the glass industry and case types,

United States, 2012

\section{Figures}

Figure 1. World demand for flat glass, 2009 (percentages) …......................................................

Figure 2. World demand for container glass, 2011 (percentages) ............................................... 9

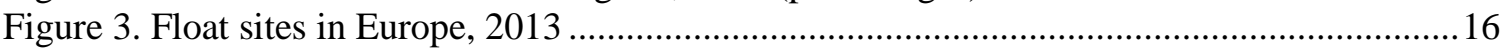

Figure 4. Employment in the glass industry in six EU countries, 2000 and 2010 .......................19

Figure 5. Incidence rate of injuries and illnesses in the US glass sector, 2011 and 2012 (per

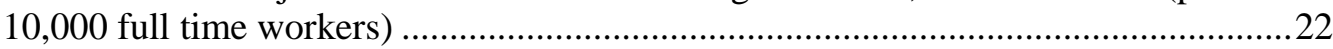

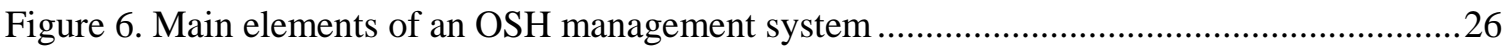

Figure 7. Recycling of container glass, selected EU countries, 2011 (percentages)....................... 31

\section{Boxes}

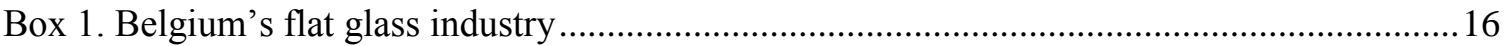

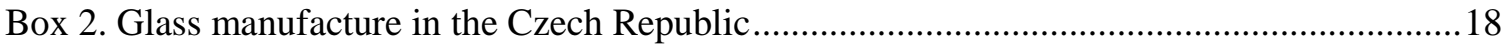

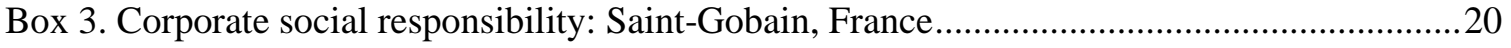

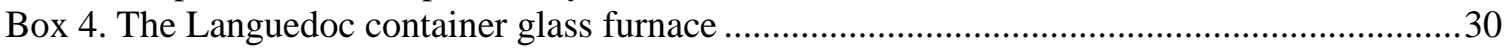




\section{Acronyms and Abbreviations}

AGC

BNDES

CBVP

$\mathrm{COSHH}$

CFA

CSR

EC

ECHA

EESC

EHS

ETUI

EU

EWC

FEVE

GDP

GFE

GMAJ

GMP

GRI

HSE

HSPP

ICEM

IFC

ILO

IndustriALL

KMWU
Asahi Glass Co., Ltd. (Japan)

National Social and Economic Development Bank, Brazil

Brazilian Flat Glass Company

Control of Substances Hazardous to Health Regulations

Committee on Freedom of Association (ILO)

corporate social responsibility

European Commission

European Chemicals Agency

European Economic and Social Committee (European Commission)

environmental health and safety

European Trade Union Institute

European Union

European Works Councils

European Container Glass Federation

gross domestic product

Glass Fibre Europe

Glass Manufacturers’ Association of Japan

Glass, Molders, Pottery, Plastics and Allied Workers International Union

Global Reporting Initiative

Health and Safety Executive (UK)

Health and Safety Partnership Program

International Federation of Chemical, Energy, Mining \& General Workers' Union

International Finance Corporation of the World Bank

International Labour Organization/International Labour Office

IndustriALL Global Union

Korean Metal Workers' Union 
LCD

liquid-crystal display

MNE

multinational enterprise

NAIMA

North American Insulation Manufacturers' Association

NEPSI

European Network for Silica

NSG

Nippon Sheet Glass (Japan)

O-I

Owens-Illinois

PPE

personal protective equipment

RCS

respirable crystalline silica

$\mathrm{REACH}$

Regulation, Registration, Evaluation, Authorisation and Restriction of Chemicals

SINTRAOISA Trade Union of Workers of Owens-Illinois Peru

SINTRAVIDRICOL Glass Workers' Union of Colombia

SVF

synthetic vitreous fibre

TWA

time-weighted average

UNITE

Unite the Union (United Kingdom)

USW

United Steelworkers of America

WEL

workplace exposure limit 


\section{Preface}

Working papers published by the ILO Sectoral Policies Department aim to disseminate research on relevant and topical issues among policy-makers, administrators, social partners, civil society, the research community and the media. Their main objective is to contribute to an informed debate on how best to address sectoral issues within the overall agenda of full and productive work for all and decent work, a goal embedded in the 2008 ILO Declaration on Social Justice for a Fair Globalization, which has now been widely endorsed by the international community.

In this era of globalization and technological progress, sectors are continuously evolving and new forms of organization of production and industrial relations are developing. The rapid changes in the world of work - especially the reorganization of production through global supply chains, the decentralization of social dialogue to the enterprise and industry levels and the impacts of the global jobs crisis on specific economic sectors - result in the emergence of new forms of employment and work arrangements, which bear on sectors in different ways. This increases the relevance of and need to develop new forms of sector-based social dialogue and innovative sectorspecific interventions.

At its 317th Session in March 2013, the ILO Governing Body instructed the Office to conduct a research study on technological progress in the glass industry and its impact on employment structure in the industry. This working paper aims to develop a better understanding of the impacts of technological changes in the industry, as well as of globalization and the financial crisis that began in 2008 , on production and employment trends both globally and in specific countries and regions.

The intensification of production systems has resulted in a decline in employment in the traditional glass-manufacturing countries, while countries such as China and Turkey have seen growth. There are also environmental issues, as well as occupational health and safety concerns.

There is as yet no formal global social dialogue forum to deal with work-related issues in the globalized glass industry. Social dialogue can serve as an effective tool to overcome the negative economic, social and political consequences of the changes taking place in the glass industry. There must be an equitable balance between voluntary initiatives and global and national laws and regulations, and governments, employers' and workers' organizations all have a pivotal role to play.

This working paper was written by Nora Wintour ${ }^{1}$, Independent Researcher.

We hope this paper will help to stimulate discussion on working conditions and employment relations in the glass industry.

Alette van Leur

Director

Sectoral Policies Department

${ }^{1}$ norawintour@live.co.uk 


\section{Executive summary}

The glass industry comprises five main sectors covering different glass products, applications and markets. These sectors are very different, whether in terms of manufacturing process, products, markets, the economics of the sectors or manufacturers, but they all transform raw materials into glass by a process of melting.

While the glass industry is based on global production, transformation and distribution, under present market conditions there are cost and transport constraints which make it uneconomic for flat and container glass to be transported long distances. However, in the case of tableware and reinforced fibre glass, these constraints, in part because of higher profit margins, do not apply to such an extent.

More than 90 per cent of glass industry products are sold to other industries. Glass manufacturing is thus significantly dependent on the building construction sector, car manufacturing and the food and beverage industry. However, there are also smaller volume sectors that produce high-value technical or consumer products.

In 2007, world glass production was estimated at a total of 115 million tonnes, with the European Union representing 32 per cent of world production. Estimates for global employment figures in the industry vary, but in general it is not labour-intensive. The flat glass and container glass industries are highly automated, while some parts of the domestic glass industry remain labourintensive.

The global market for flat glass in 2009 was approximately 52 million tonnes, representing a value at the level of primary manufacture of around $€ 22$ billion. Prior to the 2008 financial crisis, there was a steady annual rise in global demand for flat glass of 5 per cent, driven by growing demand in the construction and automotive industries. However, this growth came to a halt as global demand fell in 2008; in 2009 it contracted by 3.6 per cent. The extent of the decline was most severe in North America and Europe, where the decrease in demand was accompanied by steep declines in capacity utilization. Demand for flat glass fell an estimated 20 per cent from 2007 to 2010 in Europe. Capacity utilization, which had neared 100 per cent prior to the recession, fell to about 85 per cent by 2011 and 2012.

The significance of China as a market for glass has been increasing rapidly since the early 1990s, as the country opened to foreign investment and the economy expanded. In the early 1990s, China accounted for about one-fifth of world glass demand but is now the largest producer of glass and glass products, with just over 50 per cent of the global demand of flat glass in 2009. It has the greatest number of glass-producing enterprises and the largest number of floatglass production lines in the world. The market grew by more than 10 per cent per annum from 2000 to 2009 and demand for flat glass in China is expected to grow by 8.2 per cent annually to reach 3.4 billion square metres by 2016 . 
The glass manufacturing industry is highly concentrated. Considering flat glass production alone, four companies, Nippon Sheet Glass (NSG) Group, Asahi Glass Company (AGC), Saint-Gobain and the Guardian Group accounted for over 50 per cent of global capacity in 2010 .

The European Union is the world's largest glass market, both in terms of production and consumption. The European glass industry comprises around 1,000 companies and accounts for more than one-quarter of the non-metallic mineral sector. The glass industry in Europe, as is the case worldwide, is highly concentrated, with over 80 per cent of glass produced by fewer than a dozen multinationals each employing over 1,000 employees. The other companies are small or medium-sized, mainly producing specialist or luxury glass products. There were 180,000 people directly employed in the glass industry in the EU-27 in 2013, with up to 500,000 jobs indirectly linked to the industry. However, employment has fallen sharply, most particularly in the EU-15 countries where from 2000 to 2010 there was a 32 per cent drop in employment, from 188,000 to 129,000. The countries most affected include the main producers, France, Germany and Poland as well as Belgium, the Czech Republic and Italy. In the six major producers in Europe, there has been a loss of 50,146 jobs or an overall decline of 29 per cent, which has led to the "de-industrialization "of entire regions. As a response to short-term reduction in demand and over-capacity in production, the major MNEs have opted for plant closures and restructuring of operations to lower-cost countries. The devastating consequences of redundancies have in some instances affected whole communities which had developed around glass manufacturing, often over generations and in some cases over centuries.

There are occupational health and safety concerns in the glass manufacturing industry. In addition, there are psychosocial and physical environment impacts, with high levels of work intensity and relatively low levels of autonomy, which can result in a range of stress-related illnesses such as cardiovascular disease and mental health problems. Governments, employers and workers at both the national and international levels are increasingly recognizing the need to improve coverage and compliance on OSH and to foster improved management systems, with a preventive and promotional approach which includes workers' participation. Over the past decade, many developing countries have also taken steps to review, expand and modernize their OSH legislation, emphasizing preventive measures and shifting away from solely prescribing protection measures, in line with three framework ILO Conventions on OSH. However, in practice, achieving safe and healthy workplaces is a major challenge and the increasing use of temporary, contract and agency work poses new issues, including those associated with increased insecurity at work and work intensification.

Glass production is energy-intensive; in Europe energy costs are around 22 per cent of production costs while labour costs are around 16 per cent. Glass manufacturing is also a significant emitter of greenhouse gases (GHG), particularly carbon dioxide (CO2). The European industry has been able to reduce its energy consumption per item over the last few decades, with an impressive 55 per cent reduction for the flat glass industry between 1970 and 2000 while doubling production. 
There are some promising developments in terms of energy efficiency of glass and lead-free materials in glassware. Glass products have the potential to support the transition to a low-carbon, energy-efficient and circular economy. Many of its products could contribute to energy saving through enhanced thermal insulation with lighter and more resistant glass. For the glass industry itself, improvements to energy efficiency in production will take on increasing importance in areas such as thermal isolation of furnaces, heat recuperation from combustible gas and improvements to the combustion chambers. Increasing use of recycled glass will also reduce the need for high temperature fusion. There have also been substantial improvements in the recycling of container glass, although there are significant variations even within Europe. However, recycling in the flat glass, or building glass sector remains virtually non-existent owing to technical challenges related to ensuring sufficient purity of recycled glass. Additionally, there are few measures to provide incentives for recycling in place.

At international level, there are no formal global social dialogue mechanisms. One of the shared concerns among governments, company managements, industry representatives and union representatives is how to ensure sustainable industrial workplaces in the glass sector. The unions are advocates for the longer-term aim of developing global framework agreements, as has been achieved in other manufacturing sectors. These agreements are premised on a joint commitment to respect basic human and trade union rights, acknowledging the fundamental principles of human rights as defined in the Universal Declaration of Human Rights, the ILO Declaration on Fundamental Principles and Rights at Work (1998), the ILO Tripartite Declaration of Principles concerning Multinational Enterprises and Social Policy, as well as relevant ILO Conventions and jurisprudence and the OECD Guidelines on Multinational Companies.

In the European Union, the European Commission as well as national governments and employers' associations have taken limited initiatives to develop European and national policies designed to invest in a sustainable industrial policy for glass manufacturing in order to foster growth and investment in research and development, and to safeguard quality employment. The European Economic and Social Committee (EESC) has called for the adoption of a European industrial policy for the glass industry which should seek to balance economic, environmental and social concerns as well as responding to the need to set up a social dialogue for the sector. In addition, IndustriALL European Trade Union has recommended setting up a European sectoral social dialogue mechanism for the glass industry at European, national and company level. It argues that with 15 sectoral social dialogue committees existing in the manufacturing sector, it is now more pertinent than ever to set up a social dialogue mechanism for the glass sector.

In North America, consultation and information occurs at company level but outside any formal legal framework for social dialogue. In South America, collective agreements and occupational health and safety committees are generally well established practices but there are few opportunities for wider information sharing and consultation. In Asia, collective bargaining is less 
widespread, and where it does exist is limited in scope. Discriminatory practices against contract workers are well documented.

Operating in a less regulated and highly competitive environment, representative union organizations and other observers express concerns regarding compliance with ILO Conventions, national labour laws, occupational health and safety standards and the environmental impact of some operations on local communities. A particular concern, expressed equally in South America and Asia, is the increasing tendency to reduce the permanent workforce in favour of employing fixed-term and contract workers. 


\section{Introduction}

\subsection{Purpose of the research}

At its 317th Session in March 2013, the ILO Governing Body instructed the Office to conduct a research study on technological progress in the glass industry and its impact on employment structure (ILO, 2013).

The glass industry has changed dramatically over the last ten years. Following the financial crisis, production capacity plummeted as manufacturers closed glass plants either temporarily or permanently. There was a process of mergers and acquisitions whereby the industry consolidated. However, while mature markets suffered, emerging markets began to accelerate. The purpose of this working paper is to provide a picture of the impact of the financial crisis in the context of the globalization and global supply chains in the glass industry, with particular reference to working conditions and industrial relations.

\subsection{Scope and limitations}

The paper is essentially based on two main sources of information: firstly, a desk study of documentation available publicly; and secondly, interviews with research organizations and union leaders from the glass industry in Asia, Europe, Latin America and the United States in collaboration with the IndustriALL Global Union (IndustriALL). It has faced some limitations in that many statistical sources either do not specifically collect information on the glass industry, or in other cases the information is not available on a comparative basis for countries as significant as the United States or indeed China. Another limitation is that national statistical categories are not always comparable. 


\section{Overview of the glass industry}

\subsection{Types of glass}

The glass industry comprises five main sectors covering different glass products, applications and markets. These sectors are very different, whether in terms of manufacturing process, products, markets, the economics of the sectors and manufacturers but they all transform raw materials into glass by a process of melting. The following descriptions are adapted from Glass Alliance Europe (2015):

1. Flat glass is used in buildings (windows and facades) and automotive industries (windscreens, side and rear-side glazing, backlights and sunroofs). Flat glass is also used in solar-energy applications (photovoltaic and solar thermal panels) as well as in urban and domestic furniture, appliances, mirrors and greenhouses; almost all flat glass is made by means of the float process.

2. Container glass provides a wide range of glass packaging products for food and beverages as well as flacons for perfumery, cosmetics and pharmaceutical products to a European and world-wide customer base.

3. Continuous filament glass fibre is mainly used for the production of composite materials as weight-lightening reinforcement components. Continuous filament glass fibre applications are known as fibre-reinforced polymers or glass-reinforced plastics. The sector covers applications for the automotive and transportation sectors (such as airplanes) as well as for many other sectors including wind energy, agriculture, construction, communication, and electrical and electronic goods.

4. Domestic glass comprises the manufacturing of glass tableware, cookware and decorative items such as drinking glasses, bowls, plates, vases and ornaments.

5. Special glass has a high added value linked to its intense technological content. This sector includes a large range of products such as lighting glass, glass tubes, laboratory glassware, glass ceramics, heat-resistant glass, optical and ophthalmic glass, extra thin glass for the electronics industry such as liquid crystal display (LCD) panels, photovoltaic and radiation protection glasses.

\subsection{Production profile}

In 2007, world glass production was estimated at a total of 115 million tonnes, with the European Union representing 32 per cent of this (EESC, 2009, para. 3.1). Estimates for global employment figures in the glass industry vary, but it is not a labour-intensive industry. The flat glass and container glass industries are highly automated, while some parts of the domestic glass industry remain labour-intensive.

While the industry is based on global production, transformation and distribution, under present market conditions there are cost and transport constraints which make it uneconomic for flat and container glass to be transported long distances. However, in the case of tableware and reinforced fibre glass, these constraints, in part because of higher profit margins, do not apply to such an extent.

More than 90 per cent of glass industry products are sold to other industries. Glass manufacturing is thus highly dependent on the building construction sector, car 
manufacturing and the food and beverage industry. However, there are also smaller volume sectors that produce high-value technical or consumer products.

\section{Flat glass}

Before the 2008 financial crisis, there was a steady rise in global demand for flat glass that grew at a pace of 5 per cent annually, driven by growing demand in the construction and automotive industries. However, this growth came to a halt as global demand fell in 2008; it contracted by 3.6 per cent in 2009. The extent of the decline was most severe in Europe and North America, where the decrease in demand was accompanied by steep declines in capacity utilization.

The global market for flat glass in 2009 was approximately 52 million tonnes, representing a value at the level of primary manufacture of around €22 billion (NSG, 2010, see figure 1). Of the total global market demand in 2009, around 29 million tonnes was for high-quality float glass, three million tonnes for sheet glass and two million tonnes for rolled glass. The remaining 19 million tonnes reflects demand for lowerquality float, produced mainly in China (ibid.). China, Europe and North America together account for over 70 per cent of high-quality float demand. In South America, Brazil accounted for 70 per cent of flat glass production in 2009 (IOS, 2014).

In 2009,40 per cent of flat glass went into new buildings and the same proportion into refurbishment for buildings, while approximately five million tonnes of the flat glass produced globally was automotive glass. Globally, around 83 per cent of automotive glass went into original equipment (OE) supplied to vehicle manufacturers for new vehicles and 17 per cent into the automotive glass replacement (AGR) aftermarket. Approximately 2.3 million tonnes of flat glass in 2009 was consumed in special applications. The most notable of these was solar energy (NSG, 2010).

Figure 1. World demand for flat glass, 2009 (percentages)
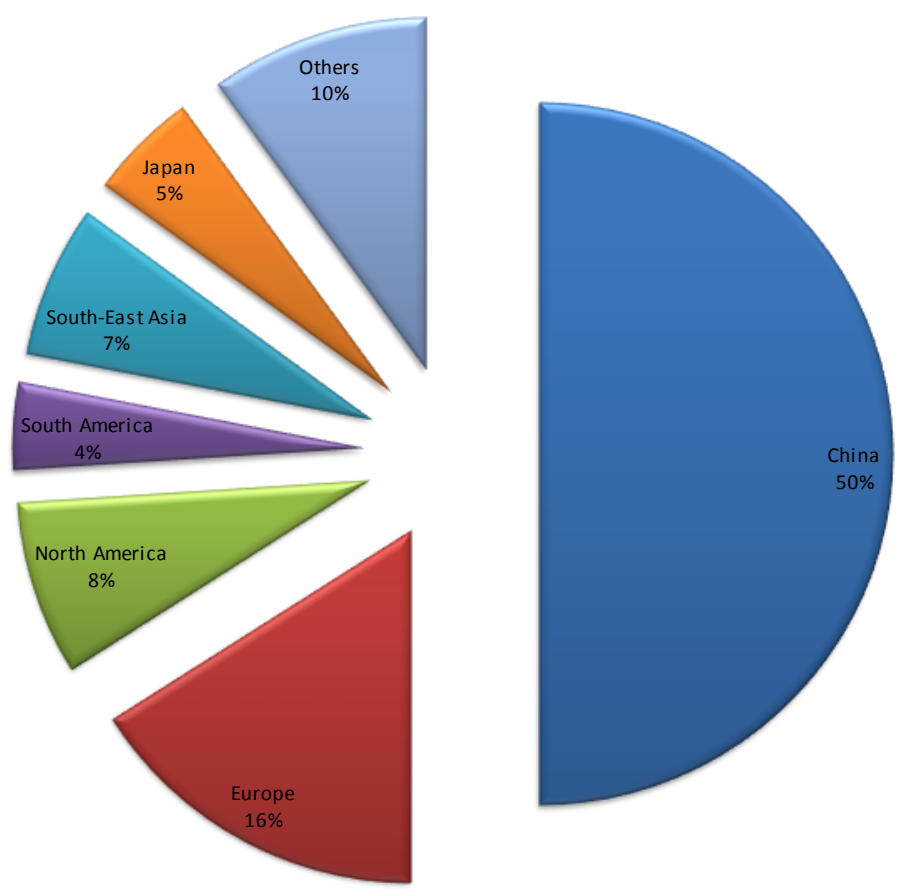

Source: NSG, 2010.

WP 310 The glass industry - Recent trends and changes in working conditions and employment relations.docx 
In North America, flat glass demand, which had reached five million tonnes with 36 float plants in operation in 2005, had dropped to slightly less than three million tonnes by 2010. As a result, capacity utilization dropped 20 per cent from 2008 to 2010 (ibid.). Since 2005, seven float lines have been shut down and another six have been closed temporarily.

Some companies report that the downturn hit the European market even harder. Demand for flat glass fell an estimated 20 per cent from 2007 to 2010. Capacity utilization, which had neared 100 per cent prior to the recession, fell to about 85 per cent by 2011 and 2012. Economic difficulties continued to depress construction and renovation in Europe, where automotive equipment markets were among the lowest levels for 20 years. Most growth has been in the Asia-Pacific region, India and Latin America.

The global market for flat glass is now expected to continue to grow over the five years 2014-19 as a result of growth in the automotive and construction industries and increasing demand for energy-efficient glass such as solar control glass and lightweight glazing, and new architectural trends. On the one hand, architectural design favours the use of large glazed facades in order to bring natural light into the built environment. The replacement of glass windows, which in mature markets is carried out every 10 to 20 years, accounts for around 40 per cent of demand and there is increasing demand for energy-efficient glass products.

\section{Production costs}

A flat glass plant is highly capital-intensive: in 2010 Pilkington estimated that a new plant costs from $€ 70$ million to $€ 200$ million. It is designed to operate continuously, 365 days per year, and its operating life, known as a campaign life, is up to 15 years. Generally speaking, plants do not become profitable until reaching over 70 per cent capacity utilization. Since float glass production is not labour-intensive, energy and raw materials costs are each as significant as labour costs. Because glass is relatively heavy and comparatively cheap, transport costs are a significant factor, making it uneconomic for glass to be transported long distances. Typically, 200 kilometres $(\mathrm{km})$ would be seen as the norm, with $600 \mathrm{~km}$ as the economic limit.

Investment costs in automotive glass production are not as high but nevertheless significant. A European automotive glazing plant, with the capacity to glaze one million cars per year, costs between $€ 42$ million and $€ 63$ million. Automotive glazing plants are more efficient with long production runs that require fewer tooling changes, and tend to be more labour-intensive than float manufacturing; growth in value-added activities is increasing this requirement. Automotive glass can and does travel significant distances.

\section{Container glass}

The highest demand for container glass is found in the Asia-Pacific region, including China with 37 per cent of world demand. Europe represented 33 per cent of world demand in 2011 (figure 2). 


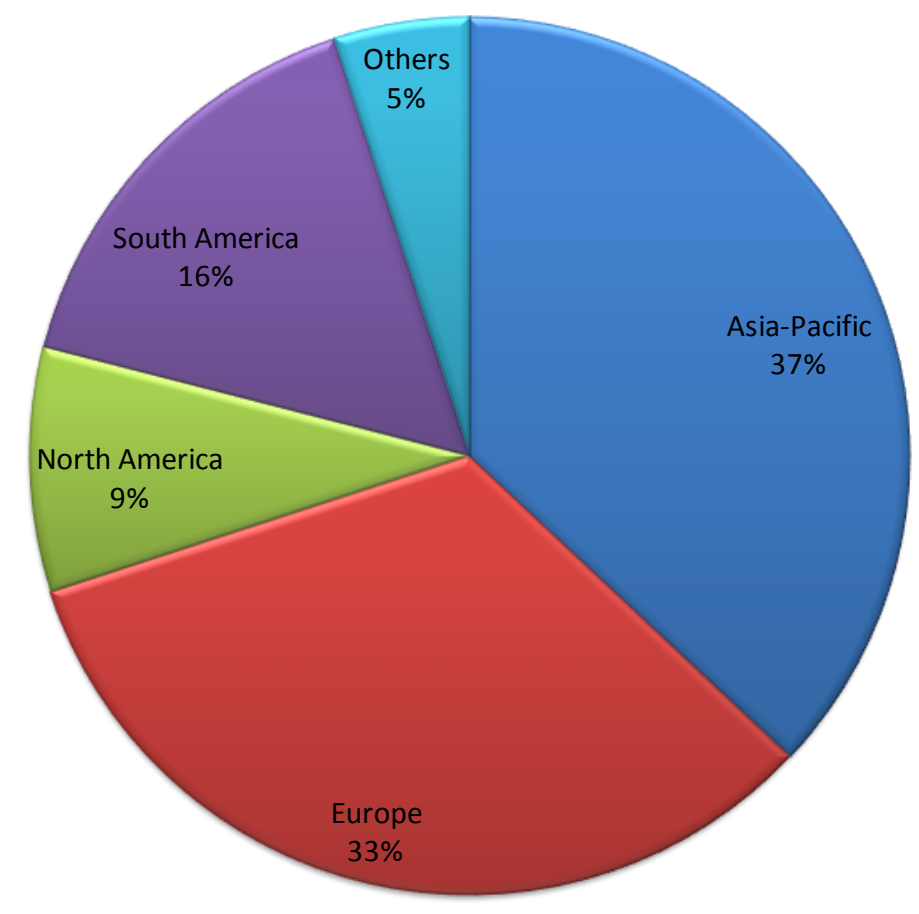

Source: IndustriALL, 2013a.

The global market for container glass packaging was valued at US $\$ 47.43$ billion in 2012 and is expected to reach US $\$ 59.94$ billion by 2019 , growing at 3.4 per cent per year from 2013 to 2019. In terms of volume, global demand was 45.71 million tonnes in 2012 and is expected to grow at 3.1 per cent per year from 2013 to 2019 (Transparency Market Research, 2014).

\subsection{Selected country and regional profiles}

\section{China}

The significance of China as a market for glass has been increasing rapidly since the early 1990s, as the country opened to foreign investment and the economy expanded. It is now the largest producer of glass and glass products worldwide, with just over 50 per cent of global output of flat glass in 2009. It has the greatest number of glass-producing enterprises and the largest number of float-glass production lines in the world. The market grew by over 10 per cent per annum between 2000 and 2009, and demand is expected to grow by 8.2 per cent annually to reach 3.4 billion square metres by 2016 .

Only approximately 1.5 per cent of Chinese float glass demand was imported during 2008, consisting primarily of specialized items that were not yet produced in China, while 11 per cent of the domestic float glass output, consisting primarily of standard glazing products, was exported. As of 2009, approximately 211 float lines were installed, but only about 50 of these were equipped to produce high quality float.

By 2008, however, China's glass industry was being heavily affected by the global economic crisis. To offset slowing global growth, the Chinese Government offered a 
RMB 4 trillion stimulus package for the next two years by promoting the growth of ten major industries, including automobiles and construction (Glassglobal Community, 2015a). These actions significantly increased the demand for glass products.

Although the quality and output of Chinese float glass has been increasing rapidly, Chinese glass companies have not yet emerged as global float glass leaders because of transport challenges, among others. Nevertheless, in the area of finished products such as picture frames and mirrors, exports from China have greatly reduced demand in the United States and elsewhere in certain market segments.

Competition from China has particularly affected those glass manufacturers with heavy solar panel investments, with significant impacts on the solar panel market in Europe and the United States over the last five years, particularly in companies that had invested in new solar panel production plants. Nippon Sheet Glass (NSG) reported heavy losses from such investments, and in 2012, Owens-Illinois (O-I) withdrew much of its investment in China, writing off a total of $€ 700$ million (Giacalone, 2013, p. 42).

It is anticipated that China's influence will continue to grow on the global glass market. If domestic demand remains strong, glass products will be required to service local needs; if demand weakens in China, then exports will rise. Several glass companies are making investments in China. Asahi Glass Company (AGC) has specifically chosen to participate in the local Chinese market through targeted added-value product initiatives. Saint-Gobain, which has had a presence in China since 1985, currently operates 54 subsidiaries and employs about 10,000 people in the country, operating several float plants directly.

\section{Brazil}

Brazil is both an importer and exporter of glass, although the majority of its production is geared towards the domestic market. Brazil imports glass principally from China (29 per cent of total glass imports) and from the United States (13 per cent). Some of the main multinational enterprises (MNEs) have also benefited from loans and guarantees made by the National Social and Economic Development Bank (BNDES) to increase production designed for the export market (table 1).

Table 1. Brazil: Production and investment in the flat glass industry, 2007-11

\begin{tabular}{|l|l|l|l|}
\hline Year & $\begin{array}{l}\text { Production capacity } \\
\text { (thousand tonnes) }\end{array}$ & $\begin{array}{l}\text { Production } \\
\text { (thousand tonnes) }\end{array}$ & $\begin{array}{l}\text { Investment } \\
\text { (US\$ millions) }\end{array}$ \\
\hline 2007 & 1240 & 992 & 37 \\
\hline 2008 & 1280 & 1152 & 230 \\
\hline 2009 & 1643 & 1164 & 50 \\
\hline 2010 & 1643 & 1309 & 248 \\
\hline 2011 & 1661 & 1516 & 207 \\
\hline
\end{tabular}

Source: Instituto Observatorio Social, 2014.

Table 1 shows that while production capacity of flat glass has remained stagnant since 2009, there has been a steady increase in production and a marked increase in investment. There are two main MNEs in flat glass production: CEBRACE, a joint venture between NSG and Saint-Gobain, with 57 per cent of total production capacity; and the Guardian Group with 43 per cent. In 2012 the Japanese multinational AGC opened a new plant for automotive glass, and in 2014 the Companhia Brasileira de Vidros Planos (CBVP), a fully-owned Brazilian company, opened a flat glass plant and has plans to expand. 
Production and investment figures for container glass, which accounted for 34 per cent of sales of glass in Brazil in 2011, are shown in table 2. The main producer is Owens-Illinois (O-I) followed by Verallia, the packaging brand company of SaintGobain. Although facing competition from other container products such as Tetra Pak, plastics and tins, the use of glass for containers is encouraged by the Brazilian Government's National Policy on Solid Wastes, adopted in 2010 because of its high potential for encouraging recycling. In Brazil, only 55 per cent of container glass is recycled. Owens-Illinois is also present in Brazil in domestic glass production under the brand name of CISPER (Observatorio Social, 2014).

Table 2. Brazil: Production and investment in the container glass industry, 2007-11

\begin{tabular}{|r|l|l|r|}
\hline Year & $\begin{array}{l}\text { Production capacity } \\
\text { (thousand } \\
\text { Tonnes) }\end{array}$ & $\begin{array}{l}\text { Production } \\
\text { (thousand tonnes) }\end{array}$ & $\begin{array}{l}\text { Investment } \\
\text { (US\$ millions) }\end{array}$ \\
\hline 2007 & 1303 & 1042 & 45 \\
\hline 2008 & 1292 & 900 & 55 \\
\hline 2009 & 1292 & 913 & n.a. \\
\hline 2010 & 1292 & 982 & 34 \\
\hline 2011 & n.a & 1090 & 70 \\
\hline
\end{tabular}

Source: Instituto Observatorio Social, 2014.

\section{Africa}

There is growing demand for flat glass in East and West Africa as well as southern Africa, fuelled by a strong construction sector. Nigeria, for example, lacks domestic flat glass manufacturing capacity and is highly dependent on imports from China, Europe and South America. Domestic demand in 2013 was estimated at 360,000 tonnes per year. In 2013, Egi MJG Float Glass, a joint venture between the Egi Community, Mara Group, JS Group and Ghani Group, established their first float glass manufacturing plant in Nigeria, the first of several facilities planned in West Africa. The production facility in Nigeria was designed to produce 500 tonnes of float glass per day for a variety of applications spanning from architectural solutions to the automotive industry (Industry Week, 2013).

\section{Australia}

Australia's glass container industry is dominated by two main companies: OwensIllinois Australia and Orora Limited (formerly Amcor Glass), which manufacture bottles and jars for packaging beverages and food products. The flat glass industry includes Viridian (CSR Limited), which is the only local float glass manufacturer, along with many small to medium firms producing a range of fabricated glass products. The industry comprised about 725 enterprises in 2014-15 and employed over 9,000 people. Industry revenues have been declining, however, due to adverse trends in the building market, product substitution in the glass container market and increased imports of glass, particularly from China (IBISWorld, 2014).

\section{Europe}

As the world's largest glass market, both in terms of production and consumption, the situation in Europe is analysed in more detail below, in section 3. 


\subsection{Employment trends}

In an industry that has not been labour-intensive, increasing intensification of production systems has resulted in a decline in employment in the traditional glassmaking countries. However, global employment figures are incomplete and difficult to interpret, in part because of varying classification systems.

The United Nations Industrial Development Organization (UNIDO) statistics for employment in the glass industry from 2000 to 2012 are shown in the Annex. Other sources report figures as follows:

- In the European Union, the industry employed 234,000 people in 2008 (Ecorys, 2008). However, employment has fallen sharply since then with over 50,000 jobs lost (see section 3).

- In the United States, over 120,000 people were employed in the industry in 2011 (Lipetz, 2011).

- An estimate by the Italian Trade Commission indicated that over 780,000 people were employed in the glass industry in China in 2011. Employment has surged since then and may have begun to do so earlier than this (the UNIDO statistics show over a million employed in the industry in 2010, see Annex 1).

- In Brazil some 8,000 people were employed in the flat glass and container glass industries in 2011 (IOS, 2014).

- In Australia the industry employed 9,150 people in 2014-15 (IBISWorld, 2014).

\subsection{Increasing consolidation of production by large multinational enterprises}

The glass manufacturing industry is highly concentrated. Considering flat glass production alone, four companies, Nippon Sheet Glass (NSG) Group, Asahi Glass Company (AGC), Saint-Gobain and Guardian Industries accounted for over 50 per cent of global capacity by 2010, as shown in table 3 . Moreover, following the acquisition of Pilkington by NSG in 2006, almost 90 per cent of the combined entity is concerned with flat glass, with 50 per cent at AGC and 12 per cent at Saint-Gobain. 
Table 3. Share of world market for flat glass, by company, 2010

\begin{tabular}{|l|l|c|}
\hline Company & Country of parent company & $\%$ of world market \\
\hline AGC & Japan & 15 \\
\hline Saint-Gobain & France & 14 \\
\hline NSG Group & Japan & 13 \\
\hline Guardian Industries & United States & 12 \\
\hline Others & & 46 \\
\hline
\end{tabular}

Over the last five to ten years, the primary global glass-making companies have remained essentially unchanged, while consolidation has occurred at the regional level. The major companies are all well-established with long histories. Saint-Gobain, the oldest of the four primary global float glass leaders, was founded in 1665; Pilkington started operations in 1826, and is now part of NSG Group, which was founded in 1918. Asahi Glass Company was founded in 1907, while Guardian Industries was established in 1932.

The last ten years have seen the disappearance of several companies, mainly through acquisitions. This is especially true in Europe. Scheuten Group's solar division went bankrupt in 2012, and its German facilities were acquired by Chinese Aikosolar. Scheuten's stake in the "Moustier4" joint-venture float line in Belgium was purchased by AGC in 2013. The market downturn also hit Interpane: in 2012, AGC purchased 51 per cent of the company. Additionally, Italy's Sangalli Group entered into a partnership with Glasswall Group, which provided finances to completely restructure the company.

Other changes are in progress as private equity firms have bought up some major companies with a view to possible new acquisitions. Additionally, some companies are changing their strategies to redefine their core businesses.

\section{Selected company profiles}

Through its acquisition of Pilkington in 2006, Nippon Sheet Glass (NSG) transformed itself from a Japanese glass company to an international group with its headquarters in Japan. It produces architectural glass, automotive glass and technical glass. In 2012, it employed 29,702 employees in 30 countries, but by 2014, its total workforce had declined to 27,000. One-third of its sales are in Japan and 17 per cent of its workforce. In 2013, its workforce in Japan amounted to 4,910 employees and it had four float lines and one rolled plate line for automotive glass, as well as specialty glass operations for building protection (NSG, 2014).

After the financial crisis, in January 2009 NSG announced a restructuring plan as a result of falling demand for its glass, particularly automotive glass. It planned job cuts of 5,800 posts over two years with the intention of reducing its global workforce by 15 per cent, and reported that the job cuts would be carried out by reducing seasonal and temporary workers. The overall objective was "to protect the business in the short term and also to re-establish profit growth from 2011 fiscal year onwards". The company said it would invest JPY 22 billion in the restructuring drive (AFP, 2009).

Saint-Gobain, a Fortune 500 company based in France, is a global company with 13 regional offices throughout the world. Founded in 1665 under Louis XIV as a royal manufacturer of mirror glass, it celebrated its 350th anniversary in 2015. In 2013 it reported a total of 190,000 permanent employees, of 90 
nationalities, with 20.5 per cent female employees. It has operations in 64 countries and 75 per cent of its workforce is based outside France.

The company designs, produces and distributes construction materials for the habitat (housing, offices and other buildings) and industrial markets. Its flat glass operations amount to 21 per cent of sales and employ 32,000 persons in 42 countries. While 40 per cent of its flat glass operations are in Europe, 27 per cent are in France alone. Its container glass operations, branded under the name Verallia, represent 9 per cent of total sales and employ 42,000 people in 14 countries.

Owens-Illinois, which specializes in glass packaging, was founded in 1903 and has its headquarters in Perrysburg, Ohio, United States. In 2014, the company had 21,100 employees in 21 countries and 75 plants: 17 in the United States, two in Canada, 13 in Latin America (Argentina, Brazil, Colombia, Ecuador, and Peru), 35 in ten European countries serving 50 countries and eight in Asia-Pacific (of which four were in China). It also had joint ventures in China, Italy, Malaysia and Viet Nam. It reported US\$6.8 million of net sales in 2014 (Owens-Illinois, 2015). The company was committed to delivering cost savings of US $\$ 155$ million by the end of 2015, including shutting down high-cost furnaces in Europe.

\section{Focus on Europe}

The EU-28 is the world's largest glass market, both in terms of production and consumption. The European glass industry comprises around 1,000 companies and accounts for more than one-quarter of the non-metallic mineral sector. As is the case worldwide, the European industry is highly concentrated, with over 80 per cent of glass produced by less than a dozen multinationals each employing more than 1,000 people. The other companies are small or medium-sized, mainly producing specialist or luxury glass products.

\subsection{International competition}

The European glass industry was particularly hard hit by the economic crisis, with production falling by 12 per cent between 2007 and 2010 (Glass Alliance Europe, 2011). Because it is so heavily dependent on demand from other sectors, in particular the automobile and construction industries, the crisis and ensuing austerity measures had a double impact. In addition, the European glass industry faced competition from low-cost countries: both tableware and solar panels were badly affected by imports from elsewhere.

Glass production in the European Union is essentially destined for the EU market, with only 9.3 per cent of production, representing 3.9 million tonnes, destined for export. The most commonly exported glass products include specialized glass (38.6 per cent of exports), tableware and crystal (25.4 per cent); the main destination countries are China and increasingly India, Japan and Turkey. While exports rose by 5.3 per cent in 2007, imports grew by 35.8 per cent and overtook exports in terms of tonnage. The price per tonne of export glass was estimated at $€ 1,780.1$ compared with the price per tonne of imported glass at $€ 1,159.5$.

Since 2004, Chinese imports of flat glass have multiplied exponentially - by a factor of ten; and since 2011 there has been a mass import of low-cost photovoltaic 
panels from China which has decimated European production. The European solar panel industry has been reduced by 42 per cent in the face of competition from Chinese imports. In addition, many other countries, such as Belarus, Egypt, Qatar, Russian Federation, Ukraine and United Arab Emirates developed additional production capacity over the five-year period 2004-09 (EESC, 2009) There are also imports of flat glass from Turkey, but these are not significantly impacting on production levels in the EU-28 (Giacalone, 2013).

\subsection{Production trends}

In 2010, the European Union produced 32 million tonnes of glass, of which 62.44 per cent was container glass, 29.4 per cent was flat glass; 3.43 per cent was domestic glass and 4.61 per cent was fibreglass and special glass. Glass production had peaked in 2007, reaching 35 million tonnes, but declined to 33 million tonnes in 2012 with a value of production of around $€ 35$ billion (EESC, 2015); by 2013 production had again declined, to 31 million tonnes. Germany is by far the largest producer, followed by Poland, France and the Czech Republic.

\section{Flat glass}

Flat glass represents around 29 per cent of the total glass sector in the European Union, with around eight million tonnes in 2013 (IndustriALL, 2013c). It is estimated that the flat glass industry directly employs around 17,000 persons in a total of about 60 production units. Production of flat glass (both float and sheet glass) is dominated by a few large producers: Saint-Gobain accounts for 25 per cent of European capacity, AGC 19 per cent, NSG 17 per cent, Şişecam 13 per cent, Guardian 12 per cent and other companies 14 per cent. These companies have global investment strategies which in recent years have tended to prioritize new investment outside Europe within the emerging economies, particularly in Asia (Giacalone, 2013).

Since 2008, there has been a marked decrease in the utilization of installed capacity because of shrinking demand. It is estimated that there was about 20 per cent overcapacity of floats in 2014 (EESC, 2015). The demand for glass from the automobile industry dropped by approximately 6-8 per cent and in the construction industry by 5-6 per cent from 2008 to 2012. This drop in demand had not been anticipated by the large companies that dominate flat glass production.

The economic crisis has been used as an opportunity to relocate some plants to other countries with lower costs, particularly to southern Europe, Eastern Europe and in one case to northern Africa. During the crisis, companies chose to halt production on a temporary basis, to delay starting up plants that had been closed for renovations, or to close down plants partially or entirely. It is estimated that 15 float plants which were still operational, out of a total of 60 plants, were closed entirely or partially from 2008-13. The decision to halt production at an operational plant can signify tens of millions of dollars. The Consultative Commission on Industrial Change (CCMI) noted that 12 out of 62 plants had stopped production in 2014 while nine new sites had been built between 2008 and 2012 in neighbouring regions outside the European Union and 16 more are planned by 2016 (EESC, 2015, para. 3.2). Hence there has been a major restructuring over this period (figure 3). Box 1 looks in more detail at the impact of these changes in Belgium. 
Figure 3. Float sites in Europe, 2013

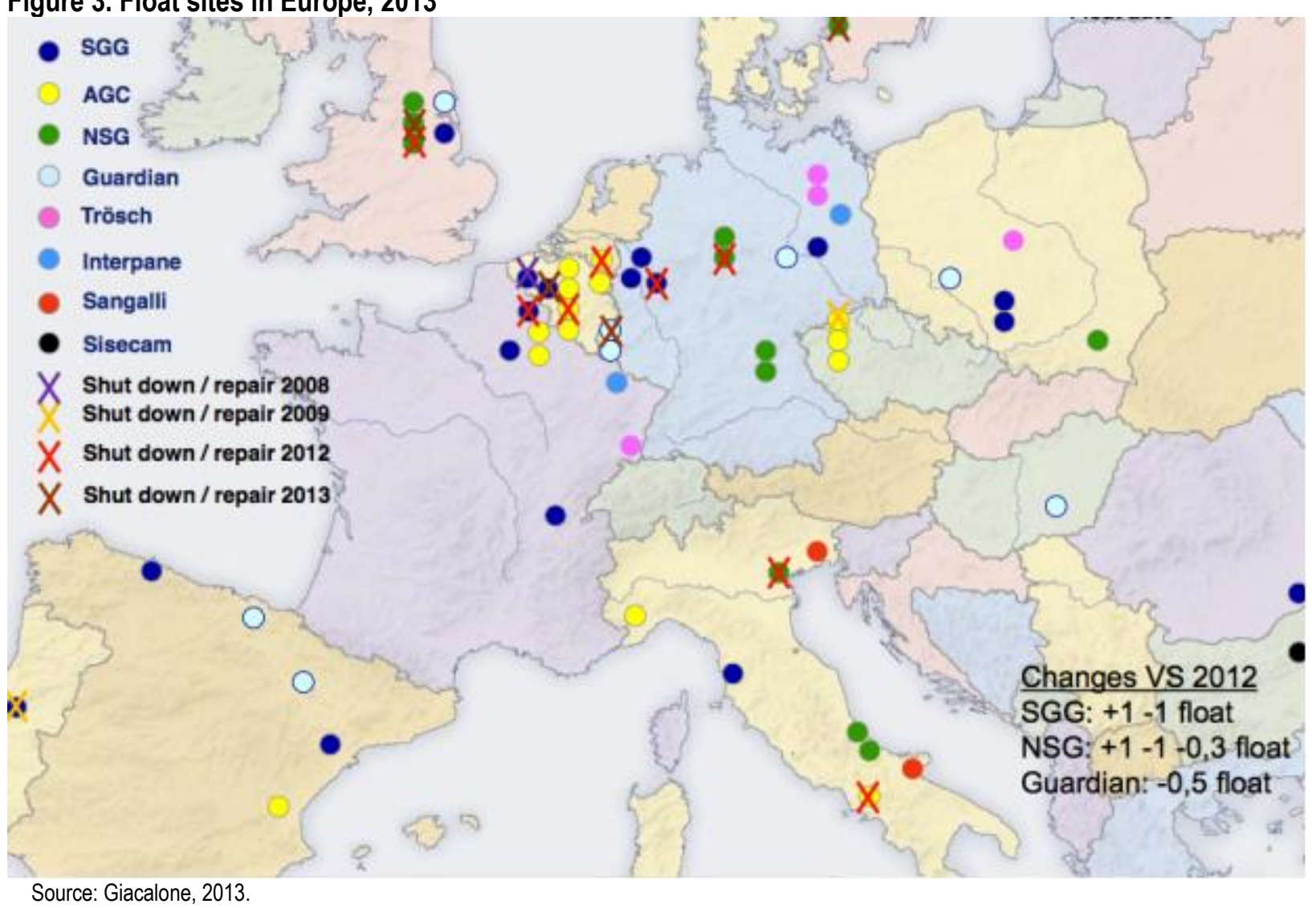

Box 1. Belgium's flat glass industry

Since the end of the 19th century Belgium, particularly the province of Hainaut, has been a centre of glass production for Europe because of its strategic location, its good sources of primary materials and its waterways. With increasing mechanization and because of the high initial capital investments required, the industry has become very concentrated. In Belgium, just ten major companies produce nearly all the different types of glass.

The glass market in Belgium is mainly for export to other European countries, principally France, Germany, the Netherlands and the United Kingdom. Nearly 80 per cent of total production is for export and the above four countries account for 60 per cent of all exports. In 2011, Belgium produced 1,060,000 tonnes of glass, compared to 1,510,000 tonnes in 2000. In terms of employment, the decrease has been even more dramatic. In 2011, there were on average 8,201 persons employed in the industry, whereas in 2000 there were 10,982 and in 1980 , the figure was 16,899 .

Unlike other countries in Europe, flat glass production in Belgium dominates the sector and represents around 88 per cent of total glass production. Because of the problem of over-capacity in Europe following the financial crisis, four of the 15 floats that were closed (although they are still fit for service) are in Belgium. The problem of over-capacity is largely explained by the sharp reduction in automobile production, which dropped by 50 per cent between 2002 and 2012 as production slowed and plants were relocated to Eastern European countries.

The competitivity of the sector in Belgium has also been affected by energy costs, relatively high labour costs compared to neighbouring countries and high production costs. The price of electricity for industrial clients in Belgium rose by 41 per cent between 2005 and 2011, while the price in Germany rose by 15 per cent, in France by 35 per cent and in the Netherlands by 4 per cent over the same period. Price differentials were largely as a result of measures taken by governments to support industry. There was a similar situation with regard to gas prices. The sector must also meet increasingly strict European environmental standards, particularly in relation to $\mathrm{CO}^{2}$ emission reduction targets. On the other hand, Belgium has a highly organized recycling system for container glass, which in 2010 reached 96 per cent, the highest rate in Europe.

Wallonia is the main glass-producing region of Belgium. AGC and Saint-Gobain are the main flat glass producers. The economic viability of the sector has been in decline since 2007; the profit margins of the nine largest companies dropped from 8.1 per cent in 2007 to 2.2 per cent in 2011.

Source: Deloitte, 2013. 


\section{Container glass}

Europe is the largest producer of container glass in the world, with an output of 20 million tonnes in 2013 (EESC, 2015). The container glass industry directly employs some 46,000 people around 160 production units in 21 countries in the European Union, Switzerland and Turkey (Deloitte, 2013). It represents 62 per cent of the glass sector in Europe (IndustriALL, 2013c).

Glass products make up around 32 per cent of packaging products for both alcoholic and non-alcoholic drinks. Plastic packaging now stands at about 37 per cent of the total and is increasing. In addition, the retail market for wine remains stagnant and exports, particularly to Asia, have decreased. Spirit retails have also decreased, because of declining purchasing power, health awareness and taxation policies. In beer retail the market remains stable, but plastic materials for packaging cheaper beers, particularly in Eastern Europe, are increasing in market share. In soft drink retail, the market for glass containers remains stable. The food retail trend for glass containers also remains stable although packaging is growing overall. The level of production of packaging glass in 2013 was approximately the same as in 2005 . It is estimated that production dropped by around ten per cent between 2008 and 2014 because of the economic crisis and the trend to relocate away from higher-cost countries (EESC, 2015).

In the face of this reduction in demand, companies adopted different strategies. Some chose to disinvest from the sector entirely, others to reduce or delay investment levels in research and in new infrastructure and others to take on high debt levels.

Recently, however, the European Container Glass Federation (FEVE, 2015) states that production volumes in the EU-28 have shown an overall increase of 1.6 per cent between 2009 and 2014. Within this period, the countries with the highest production increases included Poland, with a 7.4 per cent increase, south-eastern EU countries with 2.9 per cent, northern-central EU countries with 2.1 per cent and France with 2.2 per cent. Outside the EU zone, Turkey recorded a striking 14.8 per cent growth compared to 2013. However, these figures do not take into account production volumes before the 2008 economic crisis.

The container glass sector in Europe continues to be concentrated in a few companies in France, Germany, Italy, Spain and the United Kingdom. Since the crisis, there has been a move to relocate production facilities, particularly to Portugal and Turkey. The main companies are Owens-Illinois, Ardagh, Verallia, Vidrala, Bormioli, Vetropack and Gerresheimer. In the case of Owens-Illinois, the company closed its whole factory at Achern, Germany and three melting plants in the Czech Republic, France and Italy. At the same time, the company has invested in new machinery in its plants elsewhere, partially closing some production lines as it introduces new techniques. As a result, employees have been made redundant.

\section{Tableware glass}

The European production of tableware glass was around 1.1 million tonnes in 2013. The market for handmade tableware glass products suffered acutely after the crisis and the tendency is for tableware glass to be produced increasingly through large-scale industrial production. There is also increasing competition from low-cost countries, including Turkey and Asian countries, which has impacted negatively on countries such as France, which has a long tradition of tableware glass production. For example, the French company Arc International, founded in 1825, was formerly a major company but became heavily indebted and its workforce has been drastically cut back. From 19,000 
full-time posts in 2005, the company reduced its workforce to 12,000 full-time posts in 2010. In 2015, it was taken over by the US investment fund, Peaked Hill Partners (PHP) and currently employs 5,690 workers in France and 10,520 worldwide (Le Monde, 2015).

Handmade glass products are generally made by small and medium-sized producers. In Lorraine in the East of France, the number of such producers has drastically diminished. Baccarat, which has a workforce of 800 people, has now been taken over by two private equity firms and has restructured its finances and products and increased its levels of exports. However, many other companies in the region have closed or reduced their operations to the extent that some commentators consider that the region has lost not only its historic glass-making "savoir-faire" but its main source of wealth generation and employment (Giacalone, 2013). There have been similar job losses in the crystal glass industry in other European countries among small and mediumsized enterprises (SMEs) with historic family traditions, such as in Bohemia, Czech Republic (see box 2) and Murano, Italy (IndustriALL, 2013b).

\section{Box 2. Glass manufacture in the Czech Republic}

The traditional manufacture of glass and porcelain in Bohemia and Moravia in the Czech Republic suffered badly as a consequence of the 2008 economic crisis. Several major producers went bankrupt, including Bohemia Crystalex Trading, the Porcela Plus Group and Jablonex. It is estimated that while in 2008 there were 34,380 persons employed in the glass and ceramic industry, by 2010 this figure had dropped to 18,885 - a loss of almost 15,000 jobs. There were no wage adjustments to the collective agreement during 2009. While employment rose slightly during 2011 to approximately 20,000 and wages have also risen, the crisis has had an impact on union density levels. It has been difficult for the Trade Union of Workers in the Glass, Ceramics, Glass Jewellery and Porcelain Industry (OS SKBB) to organize in the new companies that were established as the economy recovered from the 2008 crisis.

Sources: EurWORK, 2012; ASKPCR, 2009.

\section{Glass fibre reinforced plastic (GRP)}

GRPs are critical materials for Europe's future, as they are key inputs for many innovative and environmentally-friendly applications such as lighter and more fuelefficient vehicles, wind turbines and airplanes. After the financial crisis, the production of GRPs in Europe dropped by 50 per cent from 2008 to 2009, although by 2010 it had recovered to its 2005 position. It is estimated there has been a 45 per cent reduction in the workforce since 2008. Glass Fibre Europe (GFE) estimated in 2013 that the EU workforce numbered around 5,000 direct jobs (EESC, 2015). In Germany, production dropped by 63.3 per cent and in Italy, 11.3 per cent over the period 2005-10. On the other hand, in France production increased by 18.5 per cent in the same period. The largest employers in Europe in 2010 were Amcor Glass Packaging, with a workforce of 33,000 ; and Schott, with a workforce of 17,468.

Since 2013, GRP production has risen again and grew 1 per cent in 2013 despite the difficult economic context. However, there are increasing imports from China. In 2011, Glass Fibre Europe (GFE) requested the European Commission to impose anti-dumping measures applicable to imports of certain filament glass fibre products originating from China, and in 2013 made a second request. GFE argued that China now accounts for 40 per cent of all imports of GRP into Europe; that import volumes increased 40 per cent between 2011 and 2013; and that this was made possible by illegal dumping and subsidies by the Chinese Government, state banks and local governments. It warned that if Europe loses its glass fibre manufacturing capacity, key sectors - from renewable energy 
to construction - will become dependent on inputs from China (GlassFibreEurope, 2013).

\subsection{Employment trends}

As indicated in section 3.2 above, employment preservation in the glass industry in Europe is a continuing challenge, with certain regions having been particularly badly affected.

Prior to the financial crisis, the decline in employment was due to increased productivity, mechanization and new working methods, the consolidation of the sector and competition from outside the EU countries. In 2007, total employment in the glass sector was estimated at 234,000, with 40 per cent of jobs situated in the EU-12 countries, an indication of the relative labour intensity of the sector in those countries compared to the EU-15. Poland and the Czech Republic are the main glass producers in the EU-12, with 71 per cent of the total for those countries (EESC, 2009). Productivity per employee was measured at 160.5 tonnes in 2007.

By 2013, the number of people directly employed in the glass industry in the EU-27 had fallen to 180,000 , and there were around 500,000 jobs indirectly linked to the industry. Employment fell most sharply in the EU-15 countries, from 188,000 to 129,000 between 2000 and 2010 - a 32 per cent drop. The countries most affected included the main producers - France, Germany and Poland, as well as Belgium, Czech Republic and Italy (figure 4). This trend has led to the "de-industrialization "of entire regions. The devastating consequences of redundancies have in some instances affected whole communities which had developed around glass manufacturing, often over generations and in some cases over centuries.

Figure 4. Employment in the glass industry in six EU countries, 2000 and 2010

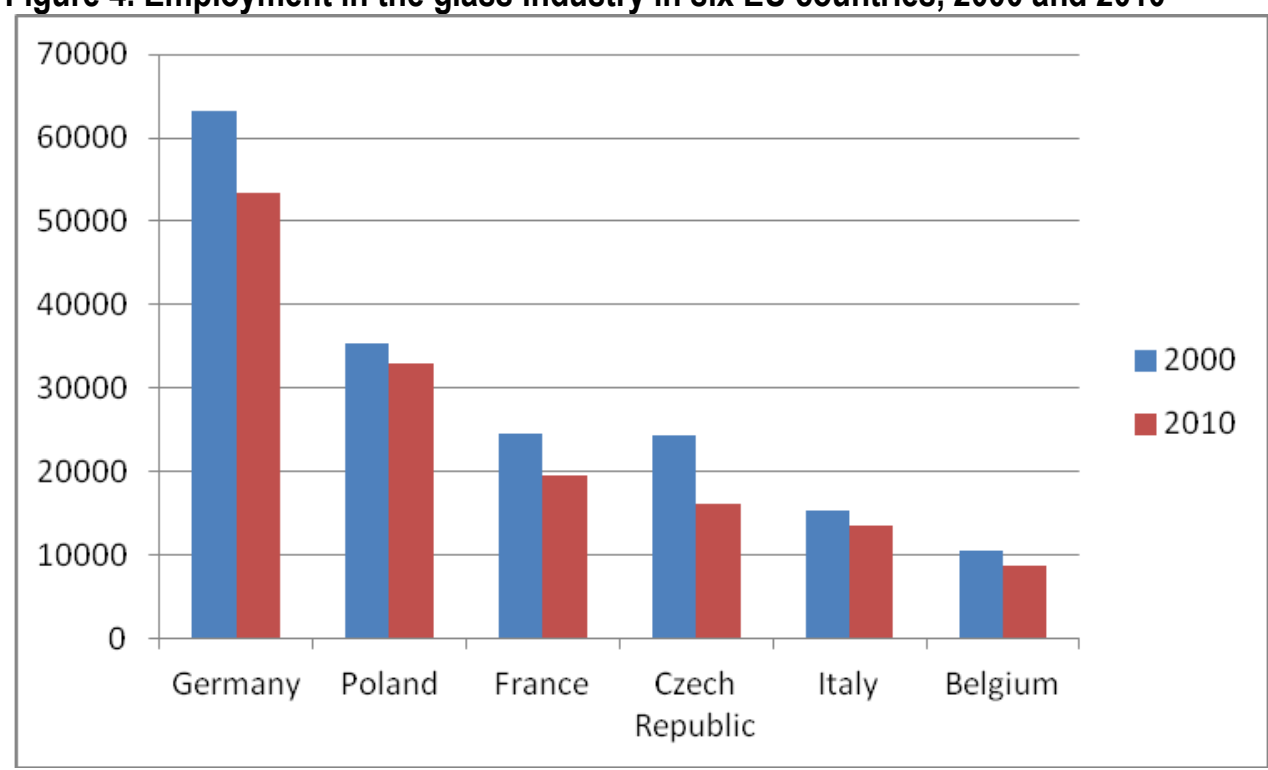

Source: Glass Alliance Europe, 2011.

A survey conducted by IndustriALL on the number of employees in the glass sector in selected countries in Europe shows the decrease in employment between 2007 and 2013, apart from Germany (table 4). Note that table 4 is an IndustriALL's estimation. Annex provides the employment figures available at the United Nations Industrial Development Organization (UNIDO), INDUST 4 2015, ISIC Revision 3. 
Table 4. Employment in the glass industry, selected European countries, 2007 and 2013

\begin{tabular}{|c|c|c|c|}
\hline Country & 2007 & 2013 & $\%$ change \\
\hline Germany & 47048 & 48109 & +2.3 \\
\hline Austria & 9808 & 8206 & -16.3 \\
\hline Belgium & 9328 & 7753 & -16.9 \\
\hline Finland & 4940 & 3353 & -32.1 \\
\hline France & 21453 & 18978 & -11.5 \\
\hline Italy & 24271 & (2012 figures) 23350 & -3.8 \\
\hline Czech Republic & 27327 & 17502 & -36.0 \\
\hline
\end{tabular}

Glass industry workers operate on a shift system. Over the last 20 years, the $4 \times 8$ shift system has gradually been replaced by the 5 X 8 system whereby there are five teams of workers, working three eight-hour shifts with two days of rest. There has also been increasing mechanization, particularly in the cold operations section where sorting, loading and unloading have all been mechanized. Many parts of the process have been outsourced and the sections which remain are the most technical in the glass forming and moulding. The posts are increasingly highly skilled. The jobs previously performed by women, such as packing, filling and finishing are now mechanized and there are fewer women employed than previously. There are a few women in technical posts, but this is not very common. ${ }^{2}$ There is also a trend towards an increasing ageing of the workforce, as the number of new recruits to the industry has diminished.

The social partners have sought to preserve employment to the extent possible and depending on the circumstances of the company (see box 3 ).

\section{Box 3. Corporate social responsibility: Saint-Gobain, France}

Saint-Gobain's 2013 report on corporate social responsibility states that the company "committed to implementing solutions to preserve jobs whenever possible and to carrying out workforce reductions only as a last resort. Instead, the Group prefers to make use of internal mobility agreements and short-time working. When restructuring is unavoidable, the employees concerned by workforce adjustments benefit from personalized support measures that can involve training, relocation assistance or support in carrying out a personal project. In France, Saint-Gobain Développement is responsible for accompanying employees in these situations" (p. 51).

Source: Saint-Gobain, 2013.

Various strategies have been used. Short-term interim measures can be negotiated if the company is undergoing temporary market adaptations, for example, reduction in working hours, partial unemployment, use of leave and training entitlements, combined with productivity agreements. In the container glass sector in France, some companies have sought to save jobs by offering reduced hours for workers between the ages of 55 and 60 years, which is partially compensated by the company.

Where companies are undergoing structural adaptations or plant closures, employment preservation strategies focus on voluntary redundancies, the terms of the redundancy offers, including investment plans for industrial reconversion and retraining opportunities. If the company is facing competitivity issues, or under-utilization of capacity, the social partners can jointly review industrial management policies and

${ }^{2}$ Fred Fournier, Secretary of the European Works Council of O-I Manufacturing and member of the Federal Bureau of the National Glass and Ceramic Federation of the General Confederation of Labour (FNTVC-CGT), correspondence with the author, 29 June 2015. 
innovative models for commercial strategies, or review the system of production units to ensure complementarity and efficiency. 


\section{Occupational health and safety in the glass manufacturing industry}

Governments, employers and workers at both the national and international levels are increasingly recognizing the need to improve coverage and compliance on occupational health and safety (OSH) and the need to foster improved management systems, with a preventive and promotional approach, which includes workers' participation. For example, ILO member States have continued to ratify the three key OSH standards: the Occupational Safety and Health Convention, 1981 (No. 155); the Occupational Health Services Convention, 1985 (No. 161); and the Promotional Framework for Occupational Safety and Health Convention, 2006 (No. 187). In June 2014, following consultations with social partners, a new EU Strategic Framework on Health and Safety at Work 2014-20 was adopted by the European Commission.

However, in practice, achieving safe and healthy workplaces in the glass manufacturing industry is a major challenge.

\subsection{Injuries and illnesses}

The glass manufacturing industry seems to have higher than average incidences of injury or illness than the manufacturing sector as a whole. For example, in the United Kingdom, the rate for all injuries in each of the glass industries is higher than the overall rate for "manufacturing" and higher than the combined rate for all industries. A similar picture exists for fatal and major injuries (HSE, 2002). Glass manufacturers in the United States reported three fatalities and 980 illnesses or injuries in 2012, up from 890 in 2011. Of these, 160 were the result of falls, slips or trips, and 390 were the result of contact with an object. Both glazing contractors and glass manufacturers reported higher than average incidence rates of injury or illness per 10,000 full-time workers during the year 133.7 for glazing contractors and 118.9 for glass manufacturers (Glass Magazine, 2014, see figure 5).

Figure 5. Incidence rate of injuries and illnesses in the US glass sector, 2011 and 2012 (per 10,000 full time workers)

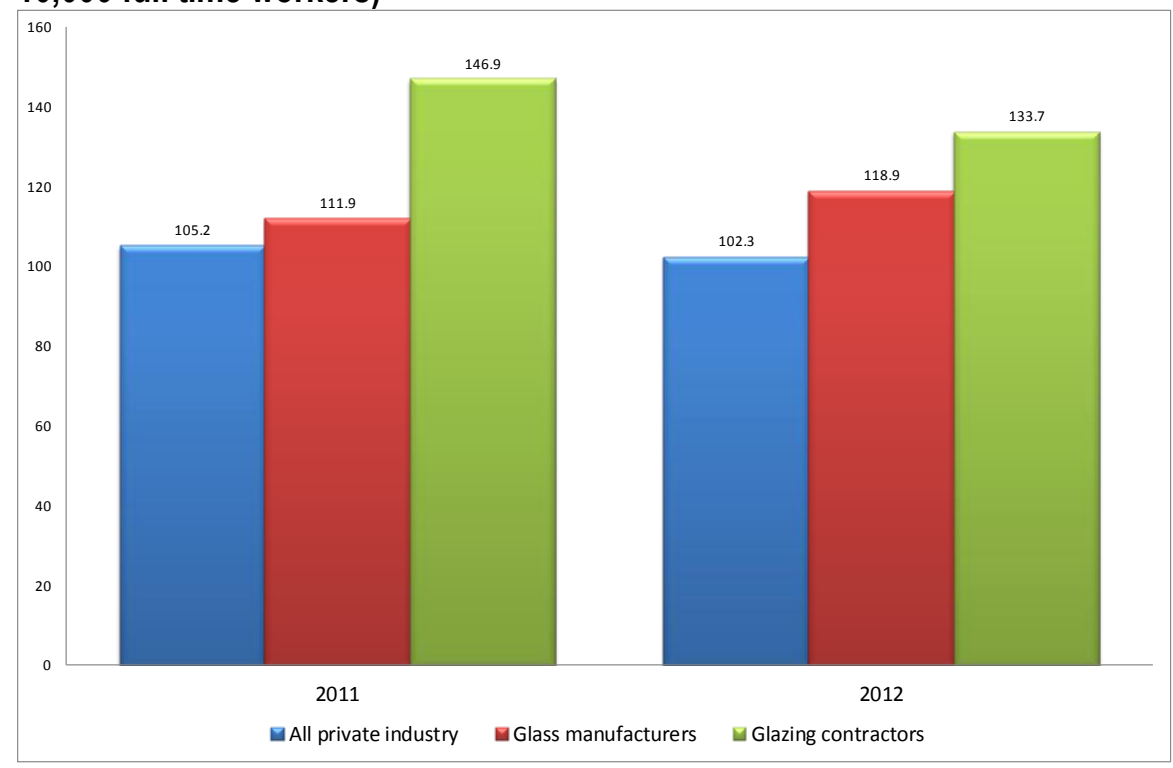

Source: Glass Magazine, 2014, from BLS 
Further details on incidence rates (per 100 full-time workers) for non-fatal occupational injuries in the glass industry in the United States, published by the US Bureau of Labor Statistics for the same year (2012), are shown in table 5.

Table 5. Incidence rates1 of non-fatal occupational injuries in the glass industry and case types, United States, 2012

\begin{tabular}{|c|c|c|c|c|c|c|}
\hline \multirow[t]{2}{*}{ Industry } & \multirow{2}{*}{$\begin{array}{l}\text { NAICS } \\
\text { (North } \\
\text { American } \\
\text { Industry } \\
\text { Classification } \\
\text { System) }\end{array}$} & \multirow{2}{*}{$\begin{array}{l}\text { Total } \\
\text { recordable } \\
\text { cases }\end{array}$} & \multicolumn{3}{|c|}{$\begin{array}{l}\text { Cases with days away from work, job } \\
\text { transfer or restriction }\end{array}$} & \multirow{2}{*}{$\begin{array}{l}\text { Other } \\
\text { recordable } \\
\text { cases }\end{array}$} \\
\hline & & & Total & $\begin{array}{l}\text { Cases with } \\
\text { days away } \\
\text { from work }\end{array}$ & $\begin{array}{l}\text { Cases with job } \\
\text { transfer or } \\
\text { restriction }\end{array}$ & \\
\hline $\begin{array}{l}\text { Glass \& glass product } \\
\text { manufacturing }\end{array}$ & 3272 & 4.9 & 2.6 & 1.2 & 1.4 & 2.4 \\
\hline $\begin{array}{l}\text { Glass \& glass product } \\
\text { manufacturing }\end{array}$ & 32721 & 4.9 & 2.6 & 1.2 & 1.4 & 2.4 \\
\hline $\begin{array}{l}\text { Other pressed and } \\
\text { blown glass and } \\
\text { glassware } \\
\text { manufacturing }\end{array}$ & 327212 & 3.9 & 2.0 & 1.0 & 1.0 & 1.9 \\
\hline $\begin{array}{l}\text { Glass container } \\
\text { manufacturing }\end{array}$ & 327213 & 4.4 & 2.4 & 0.7 & 1.6 & 2.0 \\
\hline $\begin{array}{l}\text { Glass product } \\
\text { manufacturing of } \\
\text { purchased glass }\end{array}$ & 327215 & 5.8 & 3.0 & 1.6 & 1.4 & 2.8 \\
\hline
\end{tabular}

Notes: ${ }^{1}$ The incidence rates represent the number of injuries and illnesses per 100 full-time workers and were calculated as: $(\mathrm{N} / \mathrm{EH}) \times 200,000$, where $\mathrm{N}=$ number of injuries and illnesses; $\mathrm{EH}=$ total hours worked by all employees during the calendar year; 200,000 = base for 100 equivalent full-time workers (working 40 hours per week, 50 weeks per year).

Source: BLS, 2015 (for 2012).

\subsection{Main hazards}

The main occupational health and safety concerns occur during the operational phase of glass manufacturing projects and primarily include general hazards such as exposure to heat and noise, and respiratory and physical hazards. There are other specific hazards related to exposure to chemicals, physical hazards and ergonomic hazards such as posture and movement-related hazards. In addition, there are psychosocial and physical environment impacts.

\section{Exposure to respirable crystalline silica (RCS)}

Exposure to respirable crystalline silica (RCS) through fine airborne dust affects workers in handling, mixing and transporting raw materials to the glass furnaces where the melting process occurs. According to Glass Alliance Europe (2014), around 10 per cent of the glass industry workforce is potentially exposed to RCS, or a maximum of 100,000 employees in the European Union. In Europe, over 90 per cent of workers potentially exposed to RCS are covered by risk assessments and at least 65 per cent are covered by exposure monitoring.

Over the last ten years, some cases of workers with the disease of silicosis have been reported in the glass industry in Europe. Glass Alliance Europe considers that these cases reflect working conditions and exposure in the past which are no longer prevalent. For example, the United Kingdom, has a workplace exposure limit (WEL) for RCS of $0.1 \mathrm{mg} / \mathrm{m} 3$ expressed as an 8-hour time-weighted average (TWA). Exposure to RCS is 
also subject to the Control of Substances Hazardous to Health Regulations 2002 (COSHH). There were 95 cases of silicosis in 2007 and 85 in 2008 reported from the UK Industrial Injury Disablement Benefit Scheme. Fourteen deaths from silicosis were reported in 2006 and seven in 2007 (HSE, 2015).

There are several regional and national measures in place to protect workers from silicosis. Some are briefly described below.

\section{European Network for Silica (NEPSI)}

In April 2006 an Agreement on Workers Health Protection through the Good Handling and Use of Crystalline Silica and Products containing it was signed by 17 industrial organizations representing both employers and employees (EU, 2006), which then formed the European Network for Silica. NEPSI is an example of a social voluntary agreement in the European Union on health and safety issues. Preventative medical screening of employees who are potentially exposed has shown the effectiveness of the measures, although because silicosis takes years to develop it is not yet possible to confirm whether they will prevent new cases. There have also been technical and organizational improvements, with increasing automation in the batch and melting areas where there is risk of exposure. Other risk management measures include periodic information sessions, instructions and training of workers and health protocols, including specific silicosis surveillance protocols. Other measures include the improved design of buildings, dust extraction units and improved ventilation.

\section{North American Insulation Manufacturers' Association (NAIMA) Health and Safety Partnership Program}

The synthetic vitreous fibre insulation industry (SVF) includes non-crystalline fibres produced as wool or filaments. Products include glass wool (or fibreglass), and slag wool (or mineral wool) as well as special purpose fibres for special applications such as air filtration and use in acid battery separators. The North American Insulation Manufacturers' Association (NAIMA) has developed a Health and Safety Partnership Program (HSPP) and created an occupational exposure database for glass and rock/slag wool insulation. The HSPP has also developed voluntary guidelines on permissible exposure limits for workers handling SVF insulation products; and accompanying safe work recommendations, including Personal Protective Equipment (PPE).

In 2009 , the database had 14,000 samples taken from a wide-range of employers, SVF product types, industry sectors and job functions, both in production and installation. Such databases permit the investigation of issues of interest to employers, workers and occupational health and safety experts, and the monitoring of exposure in particular job functions (Marchant et al., 2009).

\section{India: National Human Rights Commission, Expert Group on Silica Exposure}

There are an estimated 630,000 workers employed in glass and mica industries in India and a total of 3 million workers with potential risk of silica exposure. In 2003, there were documented cases of fatal exposure to silica in the glass industry in Pondicherry (NHRC, 2014a). The National Human Rights Commission of India (NHRC) has taken up the issue and called for the national Government and the states to take action to ensure its safe use. In 2009, the Commission set up an expert group on silicosis and developed a set of recommendations on prevention, remedies, rehabilitation and compensation. A first national conference was held in 2011 and a follow-up conference was convened in July 2014. The main recommendations focus on occupational health surveys, regular medical 
check-ups, improved engineering, dust control and ventilation and use of PPE (personal protective equipment). Industrial units which are "silica prone" should have bipartite occupational health and safety committees. There are also recommendations concerning treatment and compensation (NHRC, 2014b).

\section{Other national examples}

In 2001 in the United Kingdom, the Health and Safety Executive (HSE) together with employers and workers (British Glass and the Glass and Glazing Federation) launched the Glass Charter with the aim of reducing work-related accidents by 30 per cent. In France, workers exposed to asbestos between 1949 and 1996 have the right to compensation and early retirement Administration française, 2015). In the case of the Baccarat plants, 180 employees were given the right to take early retirement, as the company has been placed on a list of asbestos-affected plants. Those who opt for early retirement are guaranteed 65 per cent of their gross salary, which can be increased by enterprise agreements.

\subsection{ILO Guidelines on occupational safety and health management systems (ILO-OSH 2001)}

The positive impact of introducing OSH management systems at the organization level, both on the reduction of hazards and risks and on productivity, is now recognized by governments, employers and workers. In 2001 the ILO published the first edition of its internationally acclaimed Guidelines on occupational safety and health management systems, known as ILO-OSH 2001. They are not legally binding and are not intended to replace national laws, regulations or accepted standards, nor does their application require certification. Their purpose is described as follows:

At the onset of the twenty-first century, a heavy human and economic toll is still exacted by unsafe and unhealthy working conditions. The Guidelines call for coherent policies to protect workers from occupational hazards and risks while improving productivity. They present practical approaches and tools for assisting organizations, competent national institutions, employers, workers and other partners in establish, managing and improving occupational safety and health management systems, with the aim of reducing work-related injuries, ill health, diseases, incidents and deaths.

The Guidelines may be applied on two levels - national and organizational. At the national level, they provide for the establishment of a national framework for OSH management systems, preferably supported by national laws and regulations. They also provide precise information on developing voluntary arrangements to strengthen compliance with regulations and standards, which, in turn, lead to continual improvement of OSH performance.

At the organizational level, the Guidelines encourage the integration of OSH management system elements as an important component of overall policy and management arrangements. Organizations, employers, owners, managerial staff, workers and their representatives are motivated in applying appropriate OSH management principles and methods to improve OSH performance.

Employers and competent national institutions are accountable for and have a duty to organize measures designed to ensure occupational safety and health. The implementation of these ILO Guidelines is one useful approach to fulfilling this responsibility. (ILO, 2009).

The main elements of the system proposed include policy, organizing, planning and implementation, evaluation, and action for improvement, as shown in figure 6. 
Figure 6. Main elements of an OSH management system

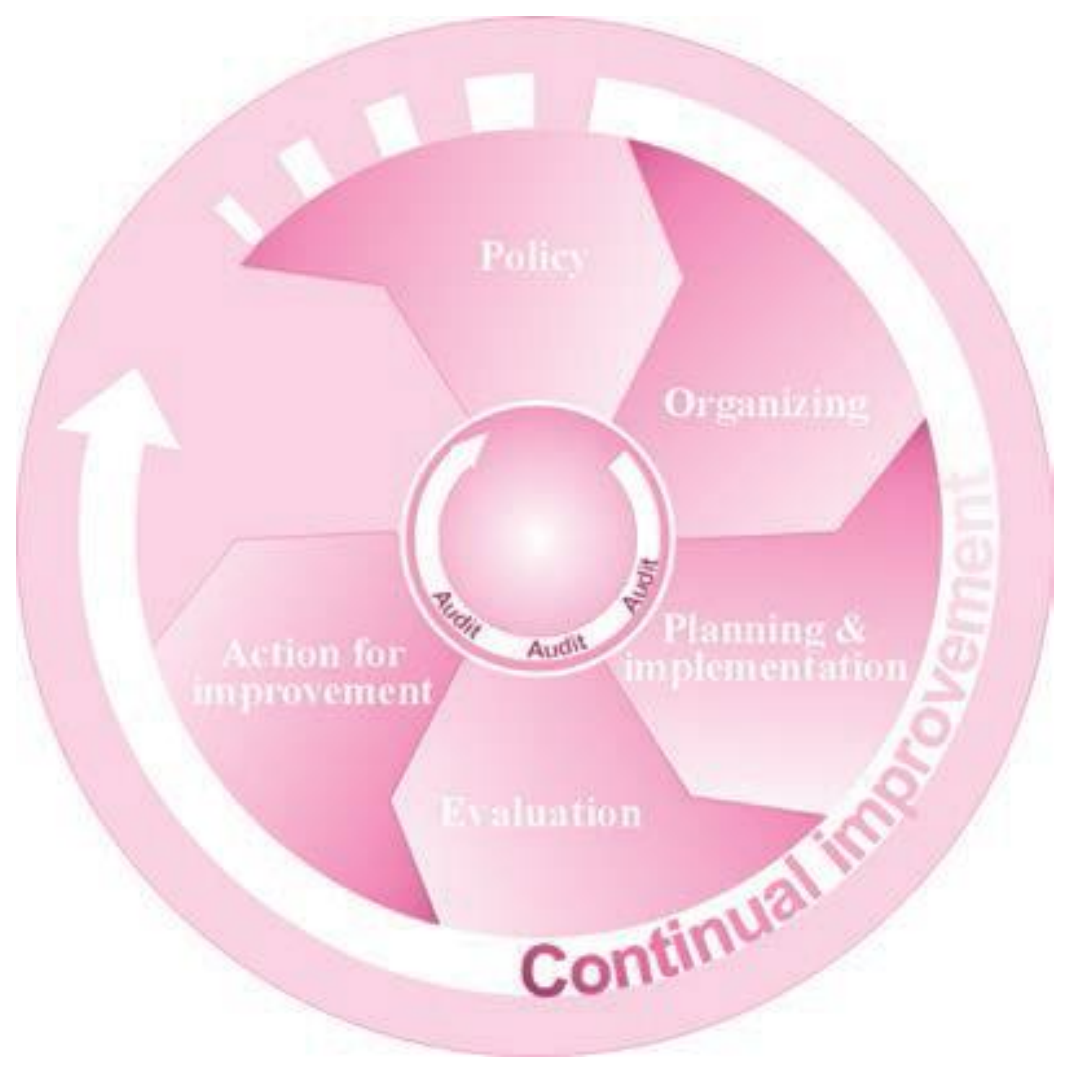

Source: ILO, 2009

\subsection{Workplace practices and OSH committees in the Asia and Americas regions}

Asia

The IndustriALL Global Union and the former International Federation of Chemical, Energy, Mining and General Workers' Union (ICEM), carried out a survey of working conditions in the glass industry in India, Indonesia, Malaysia, Thailand and Viet Nam over the period 2009-12. Union leaders nearly all reported that OHS conditions were "good" apart from one plant in Thailand, which was rated "bad' and one plant in Malaysia which was rated "medium" (IndustriALL and ICEM, 2011). However, IndustriALL notes that these ratings may not reflect reality, as union leaders are not always sufficiently well trained to recognize and report where conditions fail to meet international minimum standards. ${ }^{3}$

In one of the Saint-Gobain plants in Indonesia, the union made a complaint about the installation of cameras in the personnel changing rooms and the inadequate sanitation facilities. While there is an Occupational Safety and Health Committee, the union has not

\footnotetext{
${ }^{3}$ IndustriALL, correspondence with the author, 10 March 2015.
} 
been involved in the industrial hazards risk assessment. Workers are given medical check-ups and those at risk of chemical exposure are provided with a glass of milk each day. The female workers have the right under Indonesian law to take two days menstruation leave, although most feel constrained and do not take it. ${ }^{4}$

The Korean Chemical and Textile Workers' Federation organizes the Saint-Gobain Hangkuk Sekurit plants in Iksan and Gunsan. Communities near the plants requested further information about the nature of chemicals and other hazards used at the plant. The union and management have now signed a toxic-free agreement. (KCTF, 2014)

At the NSG plants in Japan, the Occupational Safety and Health Committees are bipartite; they are present at plant level and meet on a regular basis. Trade union representatives participate in the on-site inspections in cases of serious accidents and the trade union can provide the company with their recommendations on necessary improvements to protect workers. There have been significant improvements in OSH at the workplace since 2009; the Serious Injury Frequency Rate (SIFR) has improved from 1.0 in 2009 to 0.39 in 2014. The company has a number of OSH schemes, including "safety on vehicles and walkers", "machine safety", "safety on contractors", "safety on lifting heavy items", and "safety in driving". 5

\section{Americas}

In the United States there are joint (bi-partite) Plant Safety Committees, although the United Steel Workers union considers that there could be improvements to occupational health and safety.

At the Owens-Illinois plants in Peru, there are bi-partite Internal Committees for the Prevention of Accidents, which meet on a monthly basis to review any potential risks and insecure conditions, with the participation of the person responsible for each area.

A study from the Brazilian Instituto Observatorio Social focuses on working conditions in two Owens-Illinois plants, one in São Paulo and one in Rio de Janeiro. Information was obtained through a series of interviews with trade union leaders and workers from the two plants, both workers directly employed by the plant and contract workers (IOS, 2014).

Union leaders and workers considered that workplace accidents were common. They stated that the company only formally registered accidents when obliged, because the person had suffered a disability and needed to register for social security benefits. One respondent stated when he had needed a shoulder operation as a result of repetitive strain injury he had to take a legal case against the company so that they would formally register the injury. In Rio de Janeiro, one trade union leader had suffered a hand injury and another had a hearing impairment due to exposure to loud noise. In São Paulo, the trade union leader reported that one worker had lost an arm in 2013 and that he himself had also suffered a workplace accident.

\footnotetext{
${ }^{4}$ Interview with Tatang Supriyadi, General Secretary, FEMI, Indonesia, 19 March 2015.

${ }^{5}$ IndustriALL Japanese Affiliates Federation, correspondence with the author, 27 April 2015; and information provided by NSG trade union Japan.
} 
The company has established the statutory bodies, such as the Special Safety and Occupational Medicine Service and a bi-partite Internal Commission for the Prevention of Occupational Accidents (CIPA). In Rio de Janeiro, the collective contract states that the CIPA reports should be sent to the trade union and posted publicly on a notice board. But union leaders consider that CIPA does not function well and that the company is not interested in taking up recommendations about improvements in safety. In Rio de Janeiro, the union had requested the right to designate an expert to accompany the company expert when reviewing work conditions and wished to establish more detailed guidelines on permissible exposure limits. One trade union leader, also a member of CIPA, has taken a legal case against the company on the grounds that the company is preventing him from carrying out his mandate, as he is not allowed to visit other sections of the plant to discuss safety issues with workers (ibid.). 


\section{Environmental impacts}

Glass manufacturing is a high-temperature, energy-intensive activity leading to the emission of combustion by-products (sulphur dioxide, carbon dioxide, and nitrogen oxides) and the high-temperature oxidation of atmospheric nitrogen. Glass manufacturing is thus a significant emitter of greenhouse gases (GHG), particularly carbon dioxide $\left(\mathrm{CO}^{2}\right)$. The production of $1 \mathrm{~kg}$ of glass in a gas-fired furnace generates approximately $0.6 \mathrm{~kg} \mathrm{CO}^{2}$, of which $0.45 \mathrm{~kg}$ arises from fossil fuels combustion and 0.15 $\mathrm{kg}$ from dissociation of carbonate raw material ( ${ }^{\mathrm{CaCO} 3}$ and dolomite) used in the batch. The GHG production is directly linked with the type of glass, the type of fossil fuels used, process energy efficiency, and the use of recycled glass or cullet. Furnace emissions also contain particulate matter (PM) and may contain low levels of metals including lead and cadmium. In some special glass manufacturing, other metals, including arsenic, are found. Melting furnaces contribute between 80 and 90 per cent of the total pollutant emissions to air from a glass production facility. Emissions from the forming and finishing phases are related to the various types of glass production processes (IFC, 2007).

\subsection{Guidelines and regulations}

\section{International Finance Corporation EHS Guidelines}

The Environmental, health and safety guidelines for glass manufacturing (EHS Guidelines) from the International Finance Corporation (IFC) specify the environmental impacts of glass manufacturing, including emissions to air, wastewater and solid waste. They include a set of performance indicators for process emissions and effluents in the glass industry and are indicative of good international industry practice as reflected in relevant standards of countries with recognized regulatory frameworks.

The IFC recommends a set of procedures to control dust emissions and minimize the potential impact of raw materials transportation, handling, storage and mixing, and to implement pollution control techniques. High-efficiency dust abatement techniques are required.

Measures to increase energy efficiency, such as the use of low-carbon content fuels (e.g. natural gas, where possible, instead of fuel oil or solid fossil fuels) are also needed, together with techniques to improve furnace efficiency.

In order to limit the impact of wastewater, closed-water process systems and industrial processes for water treatment and measures to reduce water consumption are recommended. Solid waste is generated from glass manufacturing mainly in the shipping areas. Clean-up and maintenance in receiving areas can reduce this waste and allow material spills to be collected and added to the raw materials.

\section{EU environmental regulations}

In the European Union, general environmental regulations on energy consumption, $\mathrm{CO}^{2}$ emissions and pollution prevention as well as waste management and other environmental regulations all concern the glass industry. 
For the whole of the EU glass industry, it is estimated that GHG emissions amount to 20 million tonnes per year (EESC, 2009). The industry has been able to reduce its energy consumption per item over the last few decades, with an impressive 55 per cent reduction for the flat glass industry between 1970 and 2000 while doubling production (IndustriALL, 2013c). The sector falls under the EU Emissions Trading System (ETS) and is considered to be at risk of carbon leakage. The ETS system is premised on the fast reduction of free $\mathrm{CO}^{2}$ allowances. The European Commission RoadMap 2050 and RoadMap for Energy 2050 have fixed targets of $\mathrm{CO}^{2}$ carbon emission reductions of -54 per cent to -68 per cent by 2030 and between -93 per cent and -99 per cent by 2050 respectively (Deloitte, 2013). The industry is under pressure to meet rising environmental standards and develop improved production methods, including closed circuit installations and recycling of primary and secondary materials to reduce the environmental impact, and in some cases has enjoyed significant success (see box 4).

\section{Box 4. The Languedoc container glass furnace}

This plant, which supplies Perrier, has won a number of environmental awards as a result of introducing new techniques. Since 2002, the plant has reduced its use of natural gas by 30 per cent and the level of mono-nitrogen oxides (NOx) in the air by 90 per cent. In 2007, a new dust filtration system reduced the levels of heavy metal, such as silica and sulphur, to the rate of $2.1 \mathrm{mg}$ per cubic metre.

Source: Verre Online, 2015.

Energy costs in European flat glass production amount to 37 per cent of total costs. However, the European glass manufacturing associations are concerned about the increasing costs of the EU ETS and competitiveness issues (Ispy, 2013).

There are some promising developments in terms of energy efficiency of glass and lead-free materials in glassware. Glass products have the potential to support the transition to a low-carbon, energy-efficient and circular economy. Many of its products could contribute to energy saving, with enhanced thermal insulation with lighter and more resistant glass. Binding targets to reduce energy consumption in buildings as well as the development of an EU window energy label could also support increased demand for glass. For example, it has been estimated that replacing inefficient windows with high-performance glazing could save up to 100 million tonnes of $\mathrm{CO}^{2}$ per year, while supporting job creation. In its Roadmap 2015, the European Commission foresees an emissions reduction target of 90 per cent for the construction sector, by improving energy performance in new buildings so as to reach "zero emissions" by 2021.

For the glass industry itself, improvements in energy efficiency will take on increasing importance, in areas such as thermal isolation of the furnaces, heat recuperation from combustible gas and improvements to the combustion chambers. Increasing use of recycled glass will also reduce the need for high temperature fusion.

Glass has physical and chemical properties which are inert and which can be recycled continuously. Since it is made from a range of natural resources and cullet, it is a wholly recyclable product. There have been substantial improvements in the recycling of container glass, although there are significant variations within Europe (figure 7). However, recycling in the flat glass or building glass sectors remains virtually nonexistent owing to technical challenges related to ensuring sufficient purity of recycled glass. Additionally, there are few measures to provide incentives for recycling in place. 
Figure 7. Recycling of container glass, selected EU countries, 2011 (percentages)

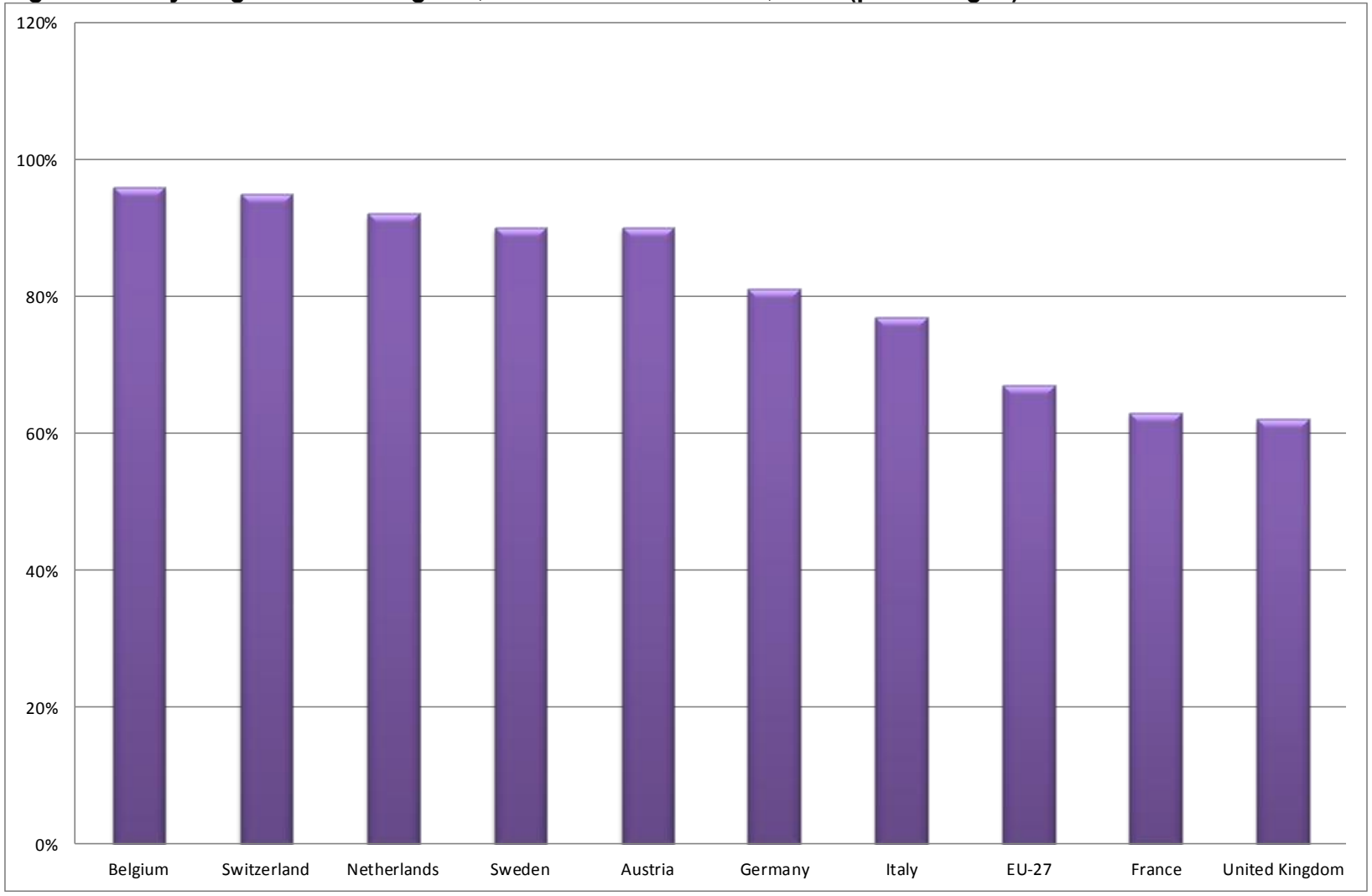

Source: FEVE, 2011. 


\section{Recent trends in social dialogue}

According to the ILO's definition:

"social dialogue includes all types of negotiation, consultation or simply exchange of information between, or among, representatives of governments, employers and workers on issues of common interest relating to economic and social policy. Social dialogue is the most suitable tool for promoting better living and working conditions and greater social justice. It is an instrument through which governance can be enhanced in many fields. It is relevant to any effort aiming to achieve more productive and effective enterprises and sectors and a fairer and more efficient economy. It thus contributes to a more stable and more equitable society. It also has particular relevance to the globalization process". (ILO, 2011)

\subsection{Social dialogue in the glass industry at global level}

At international level, there are no formal global social dialogue mechanisms in the glass industry.

The United Nations Global Compact, launched in the year 2000, describes itself as "the world's largest corporate sustainability initiative" (www.globalcompact.org). It provides a framework for businesses under ten principles in the areas of human rights, labour, the environment and anti-corruption. Under the Global Compact, companies are brought together with UN agencies, labour groups and civil society. As of 2015 it has over 8,000 corporate members from 161 countries.

Both Nippon Sheet Glass and Saint-Gobain are members of the UN Global Compact. Saint-Gobain joined in 2013 and is self-reporting, using the Global Reporting Initiative (GRI). It considers that social dialogue is essential and that it takes place at both company and facility level, in order to ensure appropriate responses to local concerns and issues. It reported 1,513 collective bargaining agreements in 2013. It also seeks to ensure that all players in the supply chain comply with local and international regulations, notably with respect for human rights, labour laws, workplace health and safety and environmental protection. In 2012 it adopted a "suppliers' charter" which explains suppliers' obligations in the area of corporate social responsibility (CSR). It also carries out CSR assessments of suppliers, using 21 environmental, social and ethical criteria, and carries out on-site audits designed to ensure that suppliers meet their commitments. In the event of non-compliance, the supplier is asked to take corrective action and a new audit may be carried out. If the issue persists, the Group may sever relations with the supplier. At national level, the company reports that basic pay standards are defined by the General Delegation (regional offices) in each country based on market conditions. The companies then establish their salary policies. The Group reports that it would like to extend its efforts to social protection systems in all host countries (Saint-Gobain, 2013).

Unions have formed a Saint-Gobain global network with a view to seeking ways to develop a global social dialogue with Saint-Gobain management, to review issues such as the company's investment strategies and its consequences for employment and the increasing trend to employ contract workers.

NSG is also a member of the UN Global Compact and has agreed to report according to the Global Reporting Index. It published its first sustainability report in 2009. Its Sustainability Report 2014 states that all suppliers must conform to ILO standards as a minimum requirement. NSG has also adopted a code of conduct to ensure 
its business activities are conducted in a safe, professional, legal and ethical manner and in a way that demonstrates corporate social responsibility and sustainability. The code acknowledges internationally proclaimed human rights which are reflected in overall employment policies and standards. The equal opportunity and diversity policy aims to prohibit discrimination based on race, colour, creed, religion and beliefs, age, gender, sexual orientation, national origin, disability, union membership, political affiliation, or any other status protected by law (NSG, 2014).

The global union federation IndustriALL Global Union (IndustriALL), has promoted the formation of MNE global union networks for the purpose of dialogue with some of the major MNEs operating in the glass industry. Through a series of conferences and workshops at national, regional and international levels, it has brought together the unions organizing in the same company, in order to exchange information on working conditions, collective bargaining and industrial relations. The unions have carried out research projects in order to assess the extent to which the MNEs are compliant with fundamental ILO Conventions, including the ILO Freedom of Association and Protection of the Right to Organise Convention, 1948 (No. 87), the Right to Organise and Collective Bargaining Convention, 1949 (No. 98), the Equal Remuneration Convention, 1951 (No. 100), the Discrimination (Employment and Occupation) Convention 1958 (No. 111), the Forced Labour Convention, 1930 (No. 29) and the Minimum Age Convention, 1973 (No. 138).

There have also been exchange programmes and study visits, and one example of a union from South America, which was experiencing difficulties in negotiating a renewal of a collective agreement, participating in the negotiations for the renewal of the collective agreement at the parent company. In some cases, the unions from the same MNE have shared collective agreements from different regions and created national MNE networks and regional networks. The purpose of the union networks is to build greater capacity for working together in defence of workers' interests across national boundaries and to promote respect for workers' rights throughout a multinational company and its supply chains.

For example, the Global Glass Alliance of Unions at Owens-Illinois was officially announced in January 2013 in a letter to the CEO, Al Strouken, as a coalition of unions representing employees in Owens-Illinois plants in North America, South America, Europe and Asia and the Pacific. It was set up in part as a response to the perceived deterioration of industrial relations within the company and because it was considered that the decisions and strategies of the company were not necessarily in the best interests of the shareholders and employees. The unions expressed an interest in strengthening the competitivity and market share of O-I in all the countries in which it operates, in the belief that these aims could be obtained at the same time as preserving fair salaries, safe working conditions and the dignity and rights of employees. The Global Glass Alliance expressed the conviction that it was in the interest of all parties that the company refrain from a conflictual approach to its relations with unions and abandon plans to introduce precarious work arrangements through contract or agency work.

In February 2013, the alliance organized a week of action to highlight the importance of strengthening social dialogue and respect for workers' rights. Actions were carried out in nine countries in North and South America, Europe and Asia-Pacific in order to raise concerns about short-term measures which were affecting the workforce, and the increasing use of contract workers. Owens-Illinois senior management acknowledged the formation of the Global Glass Alliance and promised to work in good faith with representative organizations of the workforce (IndustriALL, 2013d and 2013e). 
One of the shared concerns of governments, company management, industry representatives and union representatives is how to ensure sustainable industrial workplaces in the glass sector. The unions are advocates for the longer-term aim of developing global framework agreements, as has been achieved in other sectors. These agreements are premised on a joint commitment to respect basic human and trade union rights, acknowledging the fundamental principles of human rights as defined in the Universal Declaration of Human Rights the ILO Declaration on Fundamental Principles and Rights at Work (1998) as well as relevant ILO Conventions and the ILO Tripartite Declaration of Principles concerning Multinational Enterprises and Social Policy, and the OECD Guidelines on Multinational Companies.

In the following sections, we will examine the social dialogue practices in the glass industry at regional and national levels.

\subsection{Social dialogue in Europe}

At European level, the industry is organized by sector: Glass for Europe for the flat glass sector, FEVE for container glass, GlassFibre Europe, European Domestic Glass Committee and the European Special Glass Association. There are also two main organizations which cover all glass products at the European level: the Glass Alliance Europe and the Permanent Committee for the European Glass Industries (CPIV).

Glass Alliance Europe brings together all the glass industries to work on common issues. It is composed of 19 national glass associations and all the main sectors of the glass industry. These federations seek to coordinate the glass industries as official spokesperson before the European authorities. They also have information and advisory functions.

Social dialogue in Europe is taking place within a difficult economic and social context. The European Trade Union Institute (ETUI, 2014) has outlined some of the developments currently taking place:

- direct political intervention in national collective bargaining outcomes;

- procedures designed to ensure wage restraint;

- the decentralization of collective bargaining, for example, by enabling local-level agreements to fall below the terms of sectoral agreements or of provisions or minimum standards enshrined in the law;

- the introduction of sub-minima wages for young people and the long-term unemployed;

- the relaxation of rules governing redundancies and dismissals;

- the revision of rules governing atypical employment;

- the revision of unemployment benefit systems; and

- the weakening of occupational health and safety standards.

IndustriALL European Trade Union represents trade unions in the glass sector in Europe. It has called for national governments to be more active in protecting employment in the glass industry and preventing permanent production relocation. It 
argues that relocation is not only a threat to the industrial structure, employment and Europe's skills base but will also have long-term consequences for the environment, as there will be higher emissions and more transportation costs. It argues in favour of a European industrial policy for the glass sector in order to adopt, among others:

- an economic recovery plan for the industry;

- an increase in investments in research, development and innovation geared to a low carbon economy;

- public subsidies to maintain production and employment in regions where they have traditionally existed; and

- adjustment mechanisms at European borders as a counter-measure to companies not complying with social and environmental standards. (IndustriALL, 2013c)

The European Economic and Social Committee review (EESC 2015) of the glass sector stressed the need for a sectoral social dialogue in the glass industry in order to promote an industrial policy for the industry: "Coordination and harmonization of European policies are essential...The involvement of social partners in general and the setting of a European sectoral social dialogue, in particularly, could form an industrial policy for the glass industry." It also states: "An industrial policy for the glass industry should be informed by a sectoral social dialogue allowing social partners to exchange information on all relevant aspects of common interest to the future of this industry in Europe."

\section{European Works Councils (EWCs)}

The EWC Directive (94/45/EC) and subsequent Directive (2009/38/EC) of May 2009 established European Works Councils. As described by the European Trade Union Confederation (ETUC, 2008), the Directives apply

"to all companies with 1,000 or more workers, and at least 150 employees in each of two or more EU Member States. It obliges them to establish European Works Councils to bring together workers' representatives (usually trade unionists) from all the EU Member States the company operates in, to meet with management, receive information and give their views on current strategies and decisions affecting the enterprise and its workforce."

"Of the estimated 2,264 companies covered by the legislation, some 828 (34\%) have EWCs in operation, although the number of active EWCs is higher since some companies have set up more than one. Many of these firms are large multinationals, so the proportion of employees represented by EWCs is much higher: more than $64 \%$ or 14.5 million workers across Europe ... Among MNEs employing 10,000 people or more, 61\% have EWCs."

The EWCs are governed by procedural rules on information, consultation and negotiation. Issues fall within the competence of the EWC when they are transnational. Consultations at both European and national levels have to be ensured in the case of restructuring (EC, 2011). There is considerable diversity in the practice of the EWCs, ranging from those whose role is limited to annual meetings to those which are more proactive, maintaining regular liaison and negotiating agreements or joint texts with management. Examples include cases of cross-border restructuring rules and guidelines and a set of guarantees for employees affected by restructuring, in particular job security, measures to avoid compulsory redundancies, and accompanying measures such as retraining or redeployment (Eurofound, 2008). 
The ETUI records ten EWCs for the glass sector, though other EWCs cover both chemicals and glass (ETUI, 2015). Saint-Gobain has the earliest recorded agreement dating from 1992, prior to the first EWC directive (see below, and also box 3 in section 3 above).

The EWC meetings enable transnational exchange of information and the trade union coordinators reports they have been able to create a network of unions that can exchange information with each other, not only rely on information from the management. The EWC workers' representatives have used the opportunities to express their views concerning the companies' overall strategies, particularly when in their opinion it appeared priority was given to new investments in Asia and Latin America, at the expense of investment in and maintenance of existing facilities in many European countries.

In order to strengthen EWCs, some trade union coordinators have recommended the need for preparatory meetings with interpretation facilities and recommend that meetings be held in different countries so members of the EWC can familiarize themselves with other realities. Access to reliable economic data and quality information concerning the legal structures of the company would also facilitate informed dialogue. ${ }^{6}$

\section{Ardagh European Works Council}

The Ardagh Information and Consultation Agreement was last modified in 2012 following the amendment of the EWC Directive and the acquisition of Impresa by Ardagh, an MNE based in Ireland. It sets out in some detail the role of the EWC:

\section{Article 1: Preamble}

(3) ... Ardagh and the representatives of employees have decided to establish for their meetings a Forum of Information and Consultation. These Forum meetings will afford both parties the opportunity to construct a dialogue on the issues facing Ardagh, its subsidiaries and its employees.

\section{Article 2: Principles underlying the Forum}

The parties to this Agreement consider that the Forum should:

a) Aim to facilitate positive dialogue between employee representatives and management within the context of the agreement.

b) Not replace nor diminish existing communication initiatives for information and consultation at national and local level.

c) Contribute to a meaningful discussion about Ardagh's economic performance and understanding of the competitive business environment in the European Economic Area.

d) Ensure that employees' representatives are properly informed and consulted regarding Ardagh's decision -making and implementation processes

\section{Article 8: Meetings}

(2) All Forum meetings will cover workplace related transnational issues.

The content of the meetings to include matters of a transnational nature,

\footnotetext{
${ }^{6}$ Fred Fournier (see note 2), correspondence with the author, 5 March 2015.
} 
such as: the structure: economic and financial situation; the probable development of the business and of production and sales; the situation and probable trend of employment; investments; substantial changes concerning organization; introduction of new working methods or production processes; transfers of production; mergers; cut-backs or closures of undertakings, establishments or important parts thereof and collective redundancies.

\section{Saint-Gobain Convention for European Dialogue}

Set up in conformity with the European Social Dialogue Convention, a predecessor to the European Works Council, the Saint-Gobain Convention for European Dialogue covers 27 countries and 70 trade unions. The Group's executive management meets the union representatives, with the assistance of an independent expert, to discuss strategy and cross-border issues with the Group's executive management. It builds on national dialogue by addressing topics of common interest, such as changes in employment in industrial sites and safety issues. In France, the Saint-Gobain chairman and CEO chair the Group's Works Council and meet with central union representatives once a year.

\section{Owens-Illinois European Works Council}

With operations in several European countries (see section 2.5), Owens-Illinois saw the number of its employees in Europe drop from 9,263 in 2007 to 7,952 in 2012. The OI-EWC composition is based on the formula of one member for every 650 employees and at least one representative for each country where the company has operations. In 2006, the EWC was composed of 16 representatives. In 2011, it was reduced to 12 representatives. The Owens-Illinois EWC meets at least once a year, although in exceptional circumstances, such as redundancies or plant closures, it can meet several times. Gender representation on the Council is an issue. The workers' representatives are all male, a reflection in part of the male domination of the workforce, while the management of OI normally includes one or two women representatives.

\section{France: Social dialogue in the context of economic recession and job losses}

There have been at least 5,000 job losses in the glass industry in France over the last decade. In order to preserve employment, in 2014 the Government passed the "Loi Florange", a new law to "reconquer the real economy" whereby, in the case of companies with over 1,000 employees, the management has the obligation to inform the workers' enterprise council of any plans to close plants and effect redundancies, and to look for buyers and justify their response to each purchase offer. The workers' enterprise council has the right to have recourse to their own expert opinions and to give an opinion on any offers received (Legifrance, 2015).

In the case of Owens-Illinois, there have been three plant closures in France and the number of employees has decreased steadily from 3,371 permanent employees in 2000 to 1,897 in 2013 (Owens-Illinois, 2015). There has been no increase in the number of contract workers; in fact, there is a tendency to reduce subcontracting and reabsorb activities which had previously been outsourced. According to the Secretary of the O-I EWC, there have been no significant improvements to the collective agreement in the last three years and the quality of social dialogue has diminished over the last decade. Generally, the company maintains the strict legal minimum requirements and in some local situations has sought to limit certain trade union privileges. At present, the union's 
main demands concern wage levels, the profit-sharing scheme and in some cases, provisions concerning early retirement for those over 55 years. Unions in O-I have taken industrial action in support of salary demands and other issues. However, it is the small and medium-sized enterprises which have suffered most.

Verallia is the container glass packaging brand of Saint-Gobain and employs 2,200 workers in France in seven plants with 14 furnaces. It has around 10,000 employees worldwide. In December 2014 Saint-Gobain announced plans to put Verallia up for sale, as it plans to focus more on the building and public works section of its operations. In the United States, Saint-Gobain has already sold the North American operations of Verallia to the Irish multinational Ardagh. However, Verallia in France was a profitable business in 2013, according to a report from an analyst commissioned by the trade unions. For the Verallia trade unions, the issue is that the container glass sector requires high investment levels and Saint-Gobain's global strategy is to move into the building materials segment of its operations.

The unions' strategy is to ensure that the Verallia headquarters remains in France and that the 14 furnaces remain operational. One union estimated that for each furnace that is closed down, 120 persons are out of work and at least 400 people are affected if subcontractors are taken into account. The unions have requested the intervention of the Ministry of the Economy to prevent the company being bought by an investment company through debt leverage, which could damage the long-term perspectives for the company. In addition, they have requested the government review the situation with a view to keeping the plants open and in order to preserve jobs (Pietralunga, 2015).

\section{United Kingdom: Promoting fair pay and limiting precarious work}

In 2014 workers at Quinn Glass, a manufacturer of container glass for the food and beverages industries based in Elton, Cheshire, voted to recognize the Unite union. A spokesman for the union, which is the largest in the United Kingdom, said:

"Many Quinn Glass employees have friends or relatives who work at the Unite organised workplaces surrounding Quinn Glass - GrowHow, Essar, Shell and EOS (Electrical Oil Services). Those workplaces have become safer and more productive since union recognition, and that has enabled Unite to negotiate good terms and conditions of employment."

\footnotetext{
“Our workplace representatives work constructively with management to improve efficiency and create the right environment for success. Everyday Unite workplace representatives are helping avoid accidents and providing support for colleagues who need help with their problems at work." (Unite, 2014)
}

During three weeks in July 2014 there was strike action at two sites at Tyneside Safety Glass, in Gateshead, maker of laminated glass. The workers were represented by Unite, which argued that the company's offer of a three-year wage agreement was insufficient, particularly in the light of a 14 per cent pay increase for the director and substantial payments into the owner's trust fund. A new agreement was successfully reached following the strike action and did not include extended working hours as originally proposed. During a strike in 2010, the management had used Polish contract workers to undermine the strike and keep production going. In 2014, however, the contract workers were now members of the union and joined the strike. Unite has been a strong advocate opposing the use of temporary precarious work contracts (IndustriALL, 2014). 


\section{Turkey: Strikes suspended}

In 2014, Turkey's Şişecam Group produced 4.2 million tonnes of glass, 2.1 million tonnes of soda and 4 million tonnes of industrial raw materials. It had consolidated net sales of US $\$ 2.52$ billion, up 15 per cent compared to the previous year, and a net profit of US $\$ 153.8$ million for the year. Şişecam is the second largest glassware, third largest flat glass and fourth largest glass packaging manufacturer in Europe in terms of production capacity and has manufacturing activities in Bosnia-Herzegovina, Bulgaria, Egypt, Germany, Georgia, Hungary, India, Italy, Romania, Russian Federation, Slovakia, Turkey and Ukraine (Glassglobal Community, 2015b).

In June 2014, a major strike took place in ten companies employing 5,800 workers owned by Şişecam in Turkey. The decision to take strike action followed months of collective bargaining negotiations, when wage negotiations failed to meet expectations. In July 2014, the Turkish Government issued a decree (No. 2014/6524) to suspend the strike for 60 days on grounds of public health and national security. The decree was based on Article 63 of Act No. 6345, the Trade Union Act and Collective Labour Agreements, which effectively bans strike action as it imposes compulsory arbitration after the 60-day suspension. The Glass, Cement and Soil Workers Union, Krìstal-İs, which represents the workers in the Şişecam plants, challenged the use of this article to suspend the strike and submitted a complaint to the ILO Committee on Freedom of Association for violations of ILO Conventions, Nos. 87 and 98, arguing that the Turkish Government was systematically undermining the right to freedom of association and the right to strike (Case No. 3084). The dispute was referred to the High Arbitration Board, which ruled in a binding decision for a collective labour agreement to be in effect from 1 January 2014 to 31 December 2016 (ILO, 2015).

Strikes in the glass industry have been suspended four times since 2000, using Article 63 on the grounds that the strike was endangering national security and public health. In an earlier complaint to the ILO (Case No. 2303), the union had raised the same issue and the Committee had requested the Government to amend the legislation (ILO, 2004).

In March 2015, the Committee on Freedom of Association examined the case and

"noted with regret, that a strike has once again been suspended and compulsory arbitration imposed in the glass industry, and requests the Government to ensure in the future that such restrictions may only be imposed in cases of essential services in the strict sense of the term, public servants exercising authority in the name of the State or an acute national crisis".

It also requested the Government to amend section 63 of Act No. 6356 so that the final decision on whether to suspend a strike rests with an independent and impartial body (ILO, 2015).

\subsection{Social dialogue in the Americas}

\section{United States}

Collective bargaining in the glass industry in the United States has a long tradition; as early as the 1930s there were industry-wide collective agreements covering glassware, glass containers and window and plate glass. The Federation of Flat Glass Workers was established in 1934 (Hoeber, 1936). Today, there are national collective agreements by trade at company level. 
Owens-Illinois has 17 plants in the United States and wholly owned subsidiaries and two plants in Canada. Their workforce is represented by the United Steelworkers of America (USW). There is one plant in Colorado that does not have a union recognition agreement. Owens-Illinois acquired a new plant in 2015, which also does not have a union recognition agreement. The other plants are covered by three national agreements based on occupation. One agreement is with the USW, covering 14 plants and 850 workers in the United States in the mould-making department; one with the Glass, Molders, Pottery, Plastics and Allied Workers International Union (GMP) covering 3,500 workers in production and maintenance; and one with the International Association of Machinists and Aerospace Workers (IAM) in Auburn, New York State, covering 350 workers. Owens-Illinois reports that 77 per cent of its employees in North America (Canada and the United States) are covered by collective agreements. The company calculates that 89 per cent of the company's union-affiliated employees are covered by the main collective agreement (Owens-Illinois, 2015). All employees working at plants that are covered by the collective agreement, as a condition of employment, must become union members, or in those states where by law employees may not be required to become a union member, as a condition of employment will pay an amount to the union equivalent to its regular fees and dues (O-I/GMP Agreement, Art. 1, Section 3). The company has agreed to maintain a neutral position if the GMP carries out an organizing campaign (Art. 1 Section 7).

Each collective agreement is for a three-year period. As provided in the O-I/USW contract (Art. 40), the company will review the state of business with the union on an annual basis. There are monthly labour management meetings. The agreements cover wages, health insurance, pensions, work rules, and others. One of the major areas of concern has been the introduction of two-tiered wage and benefits packets, so that new entrants have fewer entitlements than the older workers, particularly as relates to pension plans. Also there has been workforce attrition as the company is not recruiting apprentices in the moulding department to replace workers who retire. Instead the company is importing foreign moulds and related equipment, which the USW has opposed. In 2011, there were 126 mould-makers and in 2013 the number had been reduced to 106 employees.

There are no temporary or contract workers in the facilities where the USW and GMP have collective agreements. Generally, union leaders report that industrial relations are constructive and that there is informal dialogue with corporate officials when there are requests for such meetings.

\section{Canada}

In Canada, the USW collective agreement with O-I Canada Corp., Brampton, Ontario includes non-discrimination clauses in keeping with federal human rights legislation under the Canadian Human Rights Act 1977. Clause 5.01 of the contract states:

It is agreed that there shall be no discrimination, coercion or intimidation, either by the Company or by the Union, or by their respective representatives or members against any employee because of activity or lack of activity in the Union. There shall be no discrimination against any employee male or female because of race, religion, creed, color or national origin or any category referred to in the Human Rights Code.

It also lays out provisions for an apprenticeship scheme and provides for a bi-partite apprenticeship committee with two management representatives and two qualified tradespersons who screen and recommend candidates for apprenticeships and monitor their progress through meeting with them three times per year. 
The regional headquarters of Owens-Illinois is based in Brazil, with plants in Argentina Colombia, Ecuador and Peru. It employs around 4,000 people in South America and states that approximately 86 percent of employees are covered by collective bargaining agreements (Owens-Illinois, 2015).

The company operates under two names in Brazil: Cisper and Companhia Industrial de Vidros (CIV). It produces container glass for beer, wine and other drinks, bottles for pharmaceuticals and luxury products, as well as domestic glass.

The study from the Instituto Observatorio Social (2014) mentioned earlier focuses on working conditions in two Owens-Illinois plants, one in São Paulo and one in Rio de Janeiro. In Rio de Janeiro, the workforce was 80 per cent male and comprised 500 directly employed workers and approximately 1,000 contract workers on short-term contracts of up to six months. In São Paulo, the workforce was 60 per cent male, and there were between 500-600 contract workers. The workers employed directly in both plants are covered by the respective State-wide collective contracts for glass workers. Although there is a ruling from the High Labour Court (Tribunal Superior de Trabalho) and clauses in both collective contracts stating that contract workers can only be hired to meet temporary needs, ${ }^{7}$ union leaders affirmed that contract workers were regularly employed in all aspects of production from moulding to final packing. Contract workers received the same basic pay, but did not enjoy the same benefits as those directly employed, such as additional health coverage and participation in a profit-sharing scheme. There were also many other smaller issues which caused tension and a sense of discrimination, such as not having access to the coffee room, not being allowed to use company transport facilities, fewer supplies of work uniforms and exclusion from endof-year social events.

Union representatives considered that there were no objective criteria for career progression, citing examples of workers who had been in the same position for over ten years without promotion. Another issue raised by the report was the systematic use of overtime. The working week was 44 hours but some workers reported that it was not uncommon to carry out 40 hours of overtime or to start their next shift before the legal limit of 11 hours rest. There were also occasions when workers carried out two consecutive shifts amounting to 16 hours, which is illegal under Brazilian law, as their replacement had not reported for work. There was no indication that the overtime was obligatory but workers considered that if they refused a request to carry out overtime "they were marked" (ibid., p. 51). The report also notes that many workers also have a one- to two-hour journey to work and the same to reach home.

The collective bargaining agreement is agreed between the state-level trade union of glass workers and the industry association. It does not cover the contract workers, who in the case of São Paulo represent two-thirds of the workforce. In the collective bargaining agreements, the trade unions have the right to enter the company premises once or twice a year to promote union membership and the union leaders have the right to distribute information materials and hold assemblies. Apart from the occupational health and safety committee (CIPA), there is no local trade union organization in the

${ }^{7}$ Federal Law No. 6.019, 3 January 1974, Art.2; the São Paulo Collective Contract, Clause 55; Rio de Janeiro Collective Contract of the Trade Union of the Glass Workers, Clause 33. 
company plants. Trade union leaders have the right to take paid leave (up to 25 days in the case of São Paulo).

The trade unions have not taken any legal cases against the company for noncompliance of the collective bargaining agreement. However, there are many individual cases against the company, many related to compensation claims for unhealthy working conditions. There was also one case of unfair dismissal for discrimination on grounds of sexual orientation where the company was found at fault and had to pay compensation.

The study concludes that the major area of non-compliance with the collective bargaining agreement concerns the systematic use of contract workers to perform regular duties, as a cost-saving measure to avoid paying additional benefits.

\section{Colombia}

Owens-Illinois Colombia SA has six plants. During 2012 and 2013, the glass workers' union of Colombia (SINTRAVIDRICOL) raised a series of issues concerning the breach of the collective bargaining agreement at the Owens-Illinois plant in Cogua Cundimarca. These issues included the reduction of the workforce, outsourcing sections of the manufacturing process, increased working hours and reduced rest breaks, which combined to create dangerous working conditions. SINTRAVIDRICOL also reported that a group of outsourced workers were locked out of the plant and were demanding reinstatement.

However, in 2013, following an international letter campaign to support the negotiations organized by IndustriALL and the USW, among others, the company agreed to sign with SINTRAVIDRICOL union a new 30-month collective bargaining agreement for workers at Owens-Illinois Cristaleria Peldar on 5 January 2013 (IndustriALL, 2013a). It was apparent that the international focus on the issue had facilitated the negotiations.

\section{Peru}

Owens-Illinois Peru SA is primarily engaged in the production and sale of glass containers. Its product line includes bottles and jars for basic foods, juices, beers, wines, liquors and pharmaceuticals, among others. The company operates mainly on the domestic market. Its industrial plants are located in Callao (Planta Callao) and Lima (Planta Lurín). The Company's majority shareholder is Owens-Illinois Peru STS Inc., which holds a 95.24 per cent stake in Owens-Illinois Peru SA.

There are collective bargaining agreements in place in the two plants, the latest covering a four-year period 2013-16, signed between the Trade Union of Workers of Owens-Illinois Peru (SINTRAOISA) and the company. The collective bargaining agreement covers wages, promotions, bonuses, medical and education allowances and loan facilities, but only for the permanent workers. SINTRAOISA reports that in 2005 the management had dismissed two union leaders, but that there have been no serious disputes since then. The general manager and human resources manager meet the union representatives when issues arise, generally about four times a year to improve levels of 
consultation and information, particularly in relation to disclosure of the financial position of the plants. ${ }^{8}$

\subsection{Social dialogue in Asia: Selected countries}

\section{Indonesia, Malaysia and Thailand}

The IndustriALL/ICEM study of the glass manufacturing industry over the period 2009-13 (see section 4.4 above) examined a total of 250 plants in five countries, mostly owned by MNEs. In Thailand the survey covered ten plants with a total of just over 10,000 permanent workers. In Indonesia ten plants were surveyed, with a workforce size varying from 230 to just over 1,000, for a total workforce of 3,170 permanent workers.

The numbers of fixed-term, agency or outsourced workers was particularly high in Indonesia. In the Asahimas automotive glass industry plant, there were 187 fixed-term workers (equivalent to 18 per cent of the permanent workforce) and 175 agency workers in the production line (equivalent to 17 per cent). Thus 26 per cent of the total workforce in the production line were non-permanent workers at the date of survey in March 2013. In the Asahimas flat glass plant, 35 per cent of the total workforce comprised nonpermanent workers at the date of survey in April 2009. In the Schott Igar plant, there were 100 fixed-term workers (equivalent to 33 per cent of the permanent workforce) and 30 agency workers in the production line (10 per cent). Thus, 30 per cent of the total workforce in the production line were non-permanent workers at the date of survey in July 2011.

In Thailand, only two of the four MNEs surveyed had established a collective bargaining agreement, while in Indonesia, all the ten plants had a collective bargaining agreement in force. In Malaysia, there was no collective bargaining agreement at the one MNE surveyed. Union leaders who responded to the survey reported that the provisions in the collective bargaining agreements were quite limited in scope. Indeed, in some cases, the agreements focus on the obligations of the workers to maintain efficiency and productivity rather than a negotiated agreement on the matters of mutual interest of the parties concerned.

Unions reported that there were many problems related to the increasing use of agency workers as well as obligatory overtime. The working week in Thailand was on average 60 hours, including overtime. Because wage levels are low, the report indicates that workers were willing to carry out long hours in order to meet basic needs. It was also reported that contract workers faced discrimination in terms of lower salaries, performing the worst-quality jobs and receiving fewer benefits such as social insurances and transport facilities.

In Indonesia, the General Secretary of the FEMI union has since reported that as a result of taking part in an IndustriALL training programme, which included information about the revised OECD guidelines on MNEs, the union has been able to improve the

${ }^{8}$ Daniel Santos Alburqueque Mogollon, General Secretary of SINTRAOISA, correspondence with the author, 9 April 2015. 
level of information sharing, particularly in terms of financial disclosure in order to negotiate end-of-year bonuses. ${ }^{9}$

\section{India}

Saint-Gobain started operations in India in 1996 when it acquired a majority stake in Grindwell Norton Ltd. It has eight companies in India, operating in three of its five sectors. The major companies are:

- Saint-Gobain Glass India (glass for architectural, automotive and solar segments), with plants in Tamil Nadu, Gujarat and Rajasthan

- Saint-Gobain Sekurit India (automotive glass), which manufactures and markets glazing for vehicles and the replacement markets from plants located in Maharashtra and Tamil Nadu

- Grindwell Norton (abrasives, silicon carbide, high-performance refractories, performance plastics)

\section{- SEPR Refractories India (fused refractories)}

While Saint-Gobain has plants in 20 locations in India, according to a trade union, it is said that collective bargaining agreements only cover seven plants that together have a total workforce of approximately 1,660 workers (Saint-Gobain, 2014). The management in some plants is committed to working with a mutually beneficial approach and to maintaining a dispute-free environment. In these plants, unions report that they can meet members freely and carry out inspections. However, elsewhere there are difficulties with the non-compliance of the collective bargaining agreement, particularly in relation to the widespread practice of employing contract workers. In some plants there are more fixedterm and contract workers than permanent workers. While permanent workers are union members, nearly all contract workers are not. It is reported that mandatory overtime is very common, with regular working hours in some cases of 52 hours weekly and 60 hours for contract workers. Workers are concerned that such long hours coupled with the physical and environmental conditions of glass manufacturing increase occupational health and safety hazards: many workers suffer from skin and dust allergies, back strain and industrial injuries. Union leaders report that there is a need to strengthen the provision of personal protective equipment and improve the waste management of carcinogenic materials and other waste.

There is also a trend to introduce two-tiered employment contracts so that new workers have fewer benefits and are often on short-term contracts. Other issues cited concern the practice of placing cameras in the shop floor and discrimination against union members and leaders. Union leaders report that there is very limited consultation on company policies, such as the introduction of new machinery, restructuring or information about the financial situation of the company. Communication between the unions in the different plants remains irregular (ibid.).

\footnotetext{
${ }^{9}$ Interview with Tatang Supriyadi, General Secretary, FEMI, Indonesia, 19 March 2015.
} 


\section{Republic of Korea}

In the Republic of Korea, the Korean Metal Workers' Union organizes the glass manufacturing sector with a particular focus on organizing precarious or contract workers. Enterprise-based unions which have joined KMWU, such as the OwensCorning enterprise-based union, have benefited from the national and regional collective bargaining agreements signed by KMWU with the Korean Metal Industries Employers' Association. These local or enterprise unions are able carry out local supplementary bargaining. At Owens-Corning, as elsewhere, the incidence of contract workers is high: in 2014 the union reported in 2014 that there were 227 permanent workers and 90 contract workers in the production line. The main focus of the union has been to organize these contract workers and negotiate their incorporation into the permanent workforce (KMWU, 2014).

\section{Japan}

There are three large multinationals in Japan: Asahi Glass Company (AGC), producing glass, electronics, chemicals and ceramics; Nippon Sheet Glass (NSG), producing automotive, construction and electronics glass; and Central Glass, producing flat glass. NSG has approximately 5,000 permanent employees in Japan (NSG, 2014).

The Glass Manufacturers' Association of Japan (GMAJ) represents 71 of Japan's glass companies. There is also the Glass Industry Conference of Japan.

Approximately 25 per cent of the employees are covered by collective agreements. At company level, there are joint labour-management meetings held twice a year to exchange opinions and information about matters related to strategy and operating conditions, and an annual labour affairs joint meeting to discuss wages, working conditions and other matters. At plant level, there are also regular labour-management meetings. ${ }^{10}$

\footnotetext{
10 IndustriALL Japanese Affiliates Federation, correspondence with the author, 27 April 2015; and information provided by NSG trade union Japan.
} 


\section{Bibliography}

Administration française. 2015. "Préretraite amiante du salarié du secteur privé".

Available at: http://vosdroits.service-public.fr/particuliers/F2110.xhtml.

Agence France Presse. 2009. "Nippon Sheet Glass cuts 5,800 jobs", in Industry Week, 30 Jan. Available at: http://www.industryweek.com/companies-amp-executives/nipponsheet-glass-cuts-5800-jobs.

Ardagh European Works Council. Information and Consultation Agreement, 5 May 2012 (Ireland). Available at: http://www.ewcdb.eu/show_agreement.php?agreement_ID=1765.

Association of the Glass and Ceramic Industry of the Czech Republic. Annual Report 2009. Available at: www.askpcr.cz.

Deloitte. 2013. Veille économique: Etude sur les industries du verre, Région Wallonie (Brussels).

Ecorys. 2008. FC Sector Competiveness Studies: Competitiveness in the glass sector, Final report, ENTR/06/054 (Rotterdam).

European Commission (EC). 2011. New rules for European Works Councils: Insight into Directive 2009/38/EC (Luxembourg).

European Container Glass Federation (FEVE). 2015. "EU container glass production growth shows industry resilience", press release. Available at:

http://www.feve.org/index.php?option=com_content\&view=article\&id=10\&Itemid=11.

European Economic and Social Committee (EESC). 2009. The competitiveness of the European glass and ceramics industry, with particular reference to the EU climate and energy package, opinion of the European Economic and Social Committee, CCMI/062 Glass and ceramics industry (exploratory opinion) (Brussels).

-. 2015. An industrial policy for the European glass sector, opinion of the European Economic and Social Committee, CCMI/127 Glass Industry, EESC-2014-03492-08-01NB-TRA (Brussels).

European Foundation for the Improvement of Living and Working Conditions (Eurofound). 2008. European Works Councils in practice (Dublin).

European Observatory of Working Life (EurWORK). 2012. "Glass industry recovering from the crisis", online article, 15 Aug. Available at: www.eurofound.europa.eu.

European Trade Union Confederation (ETUC). 2008. European Works Councils (EWCs) (Brussels). Available at: https://www.etuc.org/european-works-councils-ewcs.

European Trade Union Institute (ETUI). 2014. Benchmarking Working Europe 2014 (Brussels).

-. 2015. ETUI database integrating previous ETUI and SDA databases. Available at: http://www.ewcdb.eu/index.php. 
European Union (EU). 2006. Agreement on Workers Health Protection through the Good Handling and Use of Crystalline Silica and Products containing it, 25 April 2006, Notice No. 2006/C279/02, in Official Journal of the European Union, Vol. 49 (Nov.)

Giacalone, F. 2013. Note sur l'industrie verrière (Paris, Syndex). Available at: http://www.industriall-europe.eu/campaign/2013/Glass/20131023IndustriAllVerreSyndex.pdf.

Glass Alliance Europe. 2011 http://www.glassallianceeurope.eu/en/statistical-data.

-. 2014. Respirable crystalline silica in the glass industries (Brussels).

-. 2015. Website. Available at http://www.glassallianceeurope.eu/en/main-glass-sectors. GlassFibreEurope. 2013. "European glass industry calls on European Commission to investigate unfair practices of state-backed Chinese exporters", press release, Nov. (Brussels).

Glassglobal Community. 2015a. "Recovery of the glass industry in China", online article.Available at: http://www.glassglobal.com/china/.

-. 2015b. "Sisecam reports 15\% rise in sales for 2014", online article, 28 Apr. Available at: http://www.glassglobal.com/news/sisecam reports 15 rise in sales for 201425830.html.

Glass Magazine. 2014. "Rate of injury or illness higher than average in glass industry", online article, 4 Sep. Available at: http://glassmagazine.com/article/commercial/rateinjury-or-illness-higher-average-glass-industry-1412888.

Health and Safety Executive (HSE). 2002. Prevention for the health and safety in glass industries, Glass Information Sheet No. 1 (London).

--. 2015. 'Silicosis', online article. Available at: http://www.hse.gov.uk/lungdisease/silicosis.htm.

Hoeber, H. 1936. "Collective bargaining in the glass industry 1935-36", in US Department of Labor Monthly Review, Vol. 42, No. 5 (May), pp 1204-1215.

IBISWorld. 2014. Glass and glass product manufacturing in Australia: Market research report (Melbourne).

IndustriALL. 2013a. Building union power, background report, World Conference for the Materials Industries, 12-13 November 2013, Bangkok, Thailand (Geneva).

-. 2013b. Restructuring in the European glass sector, Trade Union Coordination Meeting, Saint-Gobain-AGC, Brussels, 23 October 2013 (Brussels).

-. 2013c. Resolution on the glass industry: An industrial policy to guarantee employment in the European glass sector, SL/YL industriAll 26, adopted 3 September 2013.

-. 2013d. "Owens Illinois glass workers alliance takes action", online article, 24 Jan. Available at: http://www.industriall-union.org/owens-illinois-glass-workers-alliancetakes-action. 
-. 2013e. "Owens Illinois glass workers rally across continents", online article, $14 \mathrm{Feb}$. Available at: http://www.industriall-union.org/owens-illinois-glass-workers-rally-acrosscontinents.

-. 2014. "UK glass workers strike wins pay deal", online article, 16 Jul. Available at: http://www.industriall-union.org/uk-glass-workers-strike-wins-pay-deal.

-. 2015. "Global framework agreements", online article. Available at: http://www.industriall-union.org/issues/confronting-global-capital/global-frameworkagreements.

-; International Federation of Chemical, Energy, Mining and General Workers' Union (ICEM). 2011. MNEs and Social Dialogue in Asia Project, 2010-2012: Analysis results of "My company and union", 2011 (Bangkok).

Industry Week. 2013. "New flat glass manufacturing in Nigeria could set stage for new industry", online article, 13 Jun. Available at: http://www.industryweek.com/expansionmanagement/new-float-glass-manufacturing-nigeria-could-set-stage-new-industry.

Instituto Observatorio Social (IOS). 2014. Comportamento sociotrabalhista Owens Illinois: Unidades Rio de Janeiro e São Paulo (São Paulo).

International Finance Corporation (IFC). 2007. Environmental, health and safety guidelines for glass manufacturing (Washington DC, World Bank).

International Labour Office (ILO). 2004. "335th Report of the Committee on Freedom of Association: Case No. 2303 (Turkey)”, in Official Bulletin, Vol. LXXXVII, Series B, No. 3, pp. 437-443.

-. 2009. Guidelines on occupational health and safety management systems: ILO-OSH 2001. 2nd ed. (Geneva).

-. 2011. Different views, one goal. Brochure (Geneva).

-. 2013. Sectoral Activities Programme: Proposals for 2014-2015, Governing Body, 317th Session, Geneva, Mar. 2013, GB.317/POL/5.

-. 2015. "374th Report of the Committee on Freedom of Association: Case No. 3084

(Turkey)". Available at: http://www.ilo.org/dyn/normlex/.

Ispy Publishing, Ltd. 2013. Glass Market Intelligence Report, No. 1-2013, Industry

Survey, Market Intelligence and Forecasts Series (Bolton).

Italian Trade Commission. 2011. China Glass Industry Market Report 2011 (Shanghai).

Korean Chemical and Textile Workers' Federation (KCTF). 2014. Presentation by the Saint-Gobain Hangkuk Sekurit Branch Union of the Hyeon-seok Region, IndustriALL Global Meeting on Networks in the Glass Industry, Seoul, Republic of Korea, 29-30 October 2014.

Korean Metal Workers' Union (KMWU). 2014. Presentation by the Gumi Regional Branch Owens-Corning, IndustriALL Global Meeting on Networks in the Glass Industry, Seoul, Republic of Korea, 29-30 October 2014. 
Legifrance. 2015. Loi ${ }^{\circ}$ 2014-384 du 29 mars 2014 visant à reconquérir l'économie réelle, version consolidée 8 Aug. 2015. Available at:

http://www.legifrance.gouv.fr/affichTexte.do?cidTexte=JORFTEXT000028811102\&dat $\underline{\text { eTexte}}=20150826$.

Lipetz, R. W. 2011. “Through the looking glass”, in Glass Facts (Glass Manufacturing Industry Council) (Mar.) Available at: http://www.gmic.org/Glass\%20Facts.html. Le Monde. 2015a. "Le tribunal de commerce valide la reprise d'Arc International", online article, 16 Mar. Available at:

http://www.lemonde.fr/economie/article/2015/03/16/la-reprise-d-arc-internationalvalidee-par-le-tribunal-de-commerce_4594701_3234.html.

Marchant, G.; Bullock, C.; Carter, C.; Connelly, R.; Crane, A; Fayerweather, W.; Johnson, K.; Reynolds, J. 2009. "Applications and findings of an occupational exposure database for synthetic vitreous fibres", in Journal of Occupational and Environmental Hygiene, Vol. 6, No. 3, pp. 143-150. doi: 10.1080/1545962080266438.

National Human Rights Commission (NHRC) (India). 2014a. "NHRC interventions on silicosis", presentation at the National Conference on Silicosis, New Delhi, India, 25 July 2014. Available at: http://nhrc.nic.in/.

-. 2014b. "Background note on silicosis", presentation at the National Conference on Silicosis, New Delhi, India, 25 July 2014. Available at: http://nhrc.nic.in/.

Nippon Sheet Glass (NSG). 2010. Pilkington and the flat glass industry 2010 (Tokyo). -. 2014. Sustainability Report 2014: Making a difference to our world through glass technology (Tokyo). Available at: http://www.nsg.com/en/sustainability/downloads.

Owens-Illinois, Inc.(O-I). 2015. O-I 10K: Annual Report to the US Securities and Exchange Commission for the year ending 31. 12. 2014 (Washington, DC).

Pietralunga, C. 2015. “Les salariés de Verallia appellent M. Macron à l'aide”, in Le Monde Economie (7 Feb.). Available at:

http://www.lemonde.fr/economie/article/2015/02/07/les-salaries-de-verallia-appellent-mmacron-a-1-aide_4572037_3234.html.

Saint-Gobain. 2013. Building our environment together: Corporate Social Responsibility Report 2013 (Paris). Available at: http://www.saint-gobain.com.

-. 2014. Presentation by Saint-Gobain India, IndustriALL Global Meeting on Networks in the Glass Industry, Seoul, Republic of Korea, 29-30 October 2014.

Transparency Market Research. 2014. Glass Packaging Market for Food \& Beverages, Pharmaceuticals, Beer and Other Alcoholic Beverages - Global Industry Analysis, Size, Share, Growth, Trends and Forecast 2014 - 2020 (Albany, NY). Available at:

http://www.transparencymarketresearch.com/search/search.php?search=glass+packaging \&searchId=\&searchType.

Unite. 2014. "Unite wins union recognition battle for Quinn Glass workers in Cheshire", online article, 6 Mar. Available at: http://www.unitetheunion.org/news/unite-wins-unionrecognition-battle-for-quinn-glass-workers-in-cheshire/.

Verre Online. 2015. "Verrerie du Languedoc: Fumeur, main avec filtres", online article, 26 Aug. Available at: http://www.verreonline.fr/dos_them/articles/ademe_avril2007.php. 


\section{Annex. Employment in the glass and glass production sector, selected countries,}

2000-2012

Employment in the glass and glass production sector, selected countries, 2000-2012

\begin{tabular}{|c|c|c|c|c|c|c|c|c|c|c|c|c|c|}
\hline & 2000 & 2001 & 2002 & 2003 & 2004 & 2005 & 2006 & 2007 & 2008 & 2009 & 2010 & 2011 & 2012 \\
\hline Albania & 2825 & 2945 & 2572 & 3281 & 3217 & 3277 & 3535 & 3568 & 4178 & 4113 & 4766 & 4510 & 4245 \\
\hline Austria & 9625 & 10259 & 10536 & 10518 & 10389 & 10633 & 10812 & 11063 & 10617 & & & & \\
\hline Azerbaijan & 963 & 845 & 861 & 787 & 743 & 764 & 785 & 1571 & 1893 & 1322 & & & \\
\hline Belarus & & & & & & 74188 & 74450 & 69338 & 73570 & 71883 & 72051 & 70681 & 66789 \\
\hline Belgium & 11229 & 11529 & 10714 & 10460 & 10032 & 30732 & 9147 & 9211 & & & & & \\
\hline Bermuda & 16 & 17 & 18 & 18 & 10 & 10 & 16 & 10 & 9 & 11 & 8 & 9 & 11 \\
\hline Botswana & 2137 & 2630 & 2137 & 2122 & 2798 & 2616 & 2363 & 1966 & 2604 & 2707 & 2774 & 3229 & 2657 \\
\hline Brazil & 27404 & 27407 & 27109 & 27687 & 32049 & 30073 & 32976 & 34301 & & & & & \\
\hline Bulgaria & 5169 & 4661 & 3683 & 3217 & 3145 & 4272 & 4377 & 4614 & & & & & \\
\hline Canada & 10848 & 11012 & 10866 & 10693 & 10036 & 9554 & 8842 & 8545 & 7760 & & & & \\
\hline Chile & 2271 & 2925 & 2582 & 2523 & 2976 & 2970 & 2976 & 4134 & 3484 & & & & \\
\hline China & & & & 558700 & 669200 & 685900 & 739900 & 816700 & 911100 & 907700 & 1005100 & & \\
\hline China, Macao SAR & 17 & 16 & 16 & 16 & 248 & 324 & 507 & 516 & 425 & 431 & 396 & 432 & 423 \\
\hline Colombia & 4108 & 4078 & 3988 & 4107 & 4234 & 4358 & 4458 & 5729 & 5802 & 5955 & 6428 & 6847 & 6669 \\
\hline Croatia & 1953 & 1810 & 1731 & 1837 & 1979 & 1892 & 1950 & 1992 & & & & & \\
\hline Cyprus & 222 & 209 & 201 & 211 & 209 & 204 & 226 & 249 & & & & & \\
\hline Czech Republic & 35269 & 36595 & 34918 & 32924 & 31875 & 32118 & 30393 & 29175 & & & & & \\
\hline Denmark & 2614 & 2666 & 2614 & 2592 & 2525 & 2305 & 2510 & 2376 & 2359 & & & & \\
\hline Ecuador & 452 & 511 & 476 & 476 & 520 & 588 & 577 & 770 & 764 & & & & \\
\hline Egypt & & & 14403 & & 15620 & 14071 & 33136 & & & & & & \\
\hline Eritrea & 23 & 54 & 90 & 89 & 92 & 97 & 69 & 63 & 51 & 52 & 39 & 38 & 47 \\
\hline Estonia & 800 & 800 & 800 & 1000 & 1100 & 1200 & 1300 & 1300 & & & & & \\
\hline
\end{tabular}




\begin{tabular}{|c|c|c|c|c|c|c|c|c|c|c|c|c|c|}
\hline Ethiopia & 542 & 457 & 430 & 353 & 477 & 352 & 444 & 323 & 313 & 489 & & & \\
\hline Fiji & & & 489 & 126 & 124 & 103 & & & & & & & \\
\hline Finland & 4818 & 4759 & 4594 & 4614 & 4505 & 4464 & 4722 & 4925 & 5401 & & & & \\
\hline France & 51709 & 51934 & 51090 & 49894 & 49485 & 47893 & 46758 & 45925 & 43788 & & & & \\
\hline Georgia & 686 & 327 & 246 & 281 & 283 & 310 & 319 & 303 & 268 & 401 & 485 & 329 & 376 \\
\hline Germany & 71991 & 71027 & 70104 & 64419 & 62200 & 59142 & 57698 & 59150 & 60564 & & & & \\
\hline Greece & & & & 1262 & 1205 & 1248 & 1207 & 1114 & & & & & \\
\hline Hungary & 7201 & 7148 & 6282 & 6426 & 5952 & 4820 & 4552 & 5377 & 5337 & & & & \\
\hline India & 50715 & 55091 & 48060 & 46665 & 51766 & 54638 & 53718 & 49939 & & & & & \\
\hline Indonesia & & & & 20388 & 22026 & 29577 & 28947 & 24495 & 26237 & 26274 & & & \\
\hline Iran, Islamic Republic of & 12481 & 12551 & 14607 & 14375 & 14513 & 14015 & 13735 & 14431 & 16298 & 16712 & 16829 & 15353 & \\
\hline Iraq & & & & & & & & & 3097 & 2807 & 2626 & 2555 & \\
\hline Ireland & 4222 & 4119 & 3974 & 3288 & 3288 & 3132 & 2363 & 2268 & 9731 & & & & \\
\hline Italy & 37823 & 38931 & 38524 & 39833 & 38095 & 38168 & 38111 & 37492 & 37742 & & & & \\
\hline Japan & 58108 & 53649 & 51234 & 49953 & 50144 & 48729 & 48333 & 50422 & & & & & \\
\hline Jordan & & & & 359 & 380 & 488 & 583 & 856 & 923 & 724 & 947 & & \\
\hline Kazakhstan & 18600 & 19500 & 20800 & 21500 & 23600 & 26000 & 32400 & 38400 & & & & & \\
\hline Korea, Republic of & 18769 & 19168 & 20116 & 21762 & 22285 & 23178 & 23529 & 863 & 947 & 980 & 996 & 1045 & 1073 \\
\hline Kyrgyzstan & 968 & 597 & 846 & 1325 & 1481 & 1611 & 1572 & 1565 & 1407 & & & & \\
\hline Latvia & 1105 & 1073 & 1181 & 1148 & 2066 & 2164 & 1918 & 1827 & & & & & \\
\hline Lebanon & & & & & & & & 1398 & & & & & \\
\hline Lithuania & 1781 & 1753 & 1631 & 1612 & 1671 & 2168 & 2307 & 2257 & 1982 & & & & \\
\hline Luxembourg & 3108 & 2925 & 2785 & 3241 & 3060 & 2988 & 2925 & 2802 & & & & & \\
\hline Malaysia & 11351 & 11175 & 11770 & 10115 & 8585 & 9065 & 9719 & 10823 & 9875 & & & & \\
\hline Malta & 193 & 174 & 181 & 163 & 147 & 191 & 209 & 209 & 209 & & & & \\
\hline Macedonia, FYR & & 176 & 131 & 153 & 80 & 81 & 77 & 121 & 110 & 136 & & & \\
\hline Mongolia & & & & & & & 110 & 117 & 97 & 116 & 134 & 419 & \\
\hline Morocco & 1609 & 1846 & 1969 & 1994 & 1865 & 1585 & 1909 & 1463 & 1926 & 1553 & 2113 & 2204 & 2316 \\
\hline Netherlands & 6842 & 6662 & 6305 & 6119 & 5972 & 5648 & 5735 & 5434 & 5286 & & & & \\
\hline New Zealand & 1320 & 1335 & 1270 & 1260 & 1195 & 1290 & 1260 & 1200 & 2045 & & & & \\
\hline
\end{tabular}




\begin{tabular}{|c|c|c|c|c|c|c|c|c|c|c|c|c|c|}
\hline Nigeria & & & 21256 & 20207 & 10563 & & & & & & & & \\
\hline Norway & 2015 & 2025 & 2157 & 2027 & 1993 & 1968 & 2014 & 2000 & 2027 & & & & \\
\hline Oman & 848 & 800 & 886 & 886 & 902 & 968 & 1173 & 649 & 843 & 840 & 836 & & \\
\hline Pakistan & & & & & & & 9170 & & & & & & \\
\hline Panama & 501 & 368 & 389 & 338 & & & & & & & & & \\
\hline Paraguay & & 235 & 331 & & & & & & & & & & \\
\hline Peru & & 9014 & 8619 & 8964 & 50691 & 49440 & 49420 & 50420 & & & & & \\
\hline Philippines & & 5300 & & 6976 & & 4384 & 4893 & & & & & & \\
\hline Poland & 41466 & 39777 & 38112 & 39424 & 40754 & 39858 & 39068 & 40340 & 34923 & & & & \\
\hline Portugal & 8861 & 8584 & 8165 & 8090 & 7205 & & & & 6730 & & & & \\
\hline Qatar & & & & & & & 15338 & 20009 & 23536 & 24610 & 25090 & & \\
\hline Romania & 85100 & 84000 & 77100 & 23217 & 19038 & 15993 & 12678 & 11048 & 9290 & & & & \\
\hline Russian Federation & 99456 & 105930 & 105034 & 97035 & 84703 & 77391 & 73867 & 76245 & 81341 & 72565 & 66875 & 63931 & 63992 \\
\hline Saudi Arabia & & & & & & & 65209 & 74378 & 78423 & 82324 & & & \\
\hline Singapore & 1573 & 1582 & 1822 & 1682 & 1573 & 1618 & 1609 & 1439 & 1077 & & & & \\
\hline Slovakia & 7197 & 7558 & 8100 & 7771 & 7591 & 7953 & 7531 & 7066 & 6036 & & & & \\
\hline Slovenia & 3083 & 3073 & 2827 & 2964 & 2895 & 3081 & 2843 & 2625 & & & & & \\
\hline South Africa & 6740 & 6754 & 7033 & 4950 & 5604 & 5937 & 6314 & 10801 & 10280 & 10073 & 11122 & 10165 & \\
\hline Spain & 23645 & 25298 & 25291 & 25140 & 24637 & 26005 & 25765 & 25693 & 25150 & & & & \\
\hline Sri Lanka & & & & & & & & & 195 & 568 & 589 & 524 & \\
\hline Sweden & 4814 & 5204 & 4822 & 4493 & 4226 & 4136 & 4446 & 4510 & 4238 & & & & \\
\hline Switzerland & 18788 & 19173 & & & & & & & & & & & \\
\hline Syrian Arab Republic & 47149 & 47397 & 48813 & 49234 & 49295 & 49141 & & & & & & & \\
\hline Tajikistan & 697 & 738 & 971 & 887 & 834 & 858 & 547 & 591 & 315 & 178 & 485 & & \\
\hline Tanzania, United Rep. & & 393 & 268 & 268 & 271 & 273 & 16848 & & & & & & \\
\hline Trinidad and Tobago & 396 & 412 & 478 & & & & & & & & & & \\
\hline Tunisia & & 27281 & 29108 & & & & & & & & & & \\
\hline Turkey & 13565 & 13657 & & & & & & & & & & & \\
\hline Ukraine & 34700 & 33491 & 28827 & 27462 & 26998 & 27610 & 27362 & 25204 & 23260 & 18857 & 17971 & 16938 & \\
\hline United Kingdom & 34251 & 36074 & 33184 & 32786 & 30410 & 31519 & 27493 & 26100 & & & & & \\
\hline
\end{tabular}




\begin{tabular}{|c|c|c|c|c|c|c|c|c|c|c|c|}
\hline United States & 131237 & 129971 & 114794 & 103086 & 100538 & 100919 & 99103 & 93859 & & & \\
\hline Uruguay & 118 & 122 & 387 & 418 & 444 & 519 & 685 & & & & \\
\hline Viet Nam & & 148178 & 173798 & 197686 & 216861 & 220001 & 228115 & 242052 & 251948 & 21932 & 10722 \\
\hline Yemen & 10422 & 9010 & 9380 & 8036 & 15413 & 20265 & 18817 & 13575 & & & \\
\hline
\end{tabular}

Source: UNIDO, INDSTAT 4 2015, ISIC Revision 3. Available at. http://stat.unido.org/. 